\title{
Purinergic dysregulation causes hypertensive glaucoma-like optic neuropathy
}

\author{
Youichi Shinozaki, ${ }^{1}$ Kenji Kashiwagi, ${ }^{2}$ Kazuhiko Namekata, ${ }^{3}$ Akiko Takeda, ${ }^{1}$ Nobuhiko Ohno, ${ }^{4}$ \\ Bernard Robaye, ${ }^{5,6}$ Takayuki Harada, ${ }^{3}$ Takeshi Iwata, ${ }^{7}$ and Schuichi Koizumi' \\ 'Department of Neuropharmacology, Interdisciplinary Graduate School of Medicine, and 'Department of Ophthalmology, \\ Interdisciplinary Graduate School of Medicine, University of Yamanashi, Yamanashi, Japan. ${ }^{3}$ Visual Research Project, Tokyo \\ Metropolitan Institute of Medical Science, Tokyo, Japan. ${ }^{4}$ Division of Neurobiology and Bioinformatics, National Institute \\ for Physiological Sciences, Okazaki, Aichi, Japan. ${ }^{5}$ Institute of Interdisciplinary Research and ${ }^{5}$ Institute of Biology and \\ Molecular Medicine, Université Libre de Bruxelles, Belgium. 'Division of Molecular and Cellular Biology, National Institute \\ of Sensory Organs, National Hospital Organization Tokyo Medical Center, Tokyo, Japan.
}

Glaucoma is an optic neuropathy characterized by progressive degeneration of retinal ganglion cells (RGCs) and visual loss. Although one of the highest risk factors for glaucoma is elevated intraocular pressure (IOP) and reduction in IOP is the only proven treatment, the mechanism of IOP regulation is poorly understood. We report that the $P 2 \mathrm{Y}_{6}$ receptor is critical for lowering IOP and that ablation of the $P 2 \mathrm{Y}_{6}$ gene in mice $\left(\mathrm{P}_{2} \mathrm{Y}_{6} \mathrm{KO}\right)$ results in hypertensive glaucoma-like optic neuropathy. Topically applied uridine diphosphate, an endogenous selective agonist for the $P 2 Y_{6}$ receptor, decreases IOP. The $P 2 Y_{6}$ receptor was expressed in nonpigmented epithelial cells of the ciliary body and controlled aqueous humor dynamics. $\mathrm{P}_{2} \mathrm{Y}_{6} \mathrm{KO}$ mice exhibited sustained elevation of IOP, age-dependent damage to the optic nerve, thinning of ganglion cell plus inner plexiform layers, and a reduction of RGC numbers. These changes in $\mathrm{P}_{2} \mathrm{Y}_{6} \mathrm{KO}$ mice were attenuated by an IOP lowering agent. Consistent with RCC damage, visual functions were impaired in middle-aged $\mathrm{P}_{2} \mathrm{Y}_{6} \mathrm{KO}$ mice. We also found that expression and function of $\mathrm{P}_{2} \mathrm{Y}_{6}$ receptors in WT mice were significantly reduced by aging, another important risk factor for glaucoma. In summary, our data show that dysfunctional purinergic signaling causes IOP dysregulation, resulting in glaucomatous optic neuropathy.

License: This work is licensed under the Creative Commons Attribution 4.0 International License. To view a copy of this license, visit http:// creativecommons.org/licenses/ by/4.0\%.

Conflict of interest: YS, KK, and SK have submitted a patent application pertaining to the P2Y6KO mouse as a glaucoma model (patent no. 2016173485).

Submitted: February 16, 2017

Accepted: August 24, 2017

Published: October 5, 2017

Reference information: JCI Insight. 2017;2(19):e93456 https://doi.org/10.1172/jici. insight.93456.

\section{Introduction}

Glaucoma is the second most common cause of blindness and affects more than 70 million people worldwide $(1,2)$. Elevated intraocular pressure (IOP) is one of the highest risk factors for glaucoma, and lowering IOP is the first-line therapy, which prevents or delays vision loss $(3,4)$. ATP and nucleotides are present in the aqueous humor (5). Nucleotides are released from various tissues and cells, including lens (6), trabecular meshwork (7), whole retina (8), corneal endothelial cells (9), retinal ganglion cells (RGCs) (10), retinal astrocytes (11), and ciliary body (CB) (12). ATP levels in the aqueous humor are highly elevated in glaucoma patients $(13,14)$, and although IOP and ATP levels in the aqueous humor are positively correlated in patients (14), their interaction is undefined. Extracellular nucleotides including ATP bind to purinergic $\mathrm{P} 2$ receptors (15). $\mathrm{P} 2$ receptors are divided into $\mathrm{P} 2 \mathrm{X}$ and $\mathrm{P} 2 \mathrm{Y}$ receptor subfamilies. Among P2Y receptors, $\mathrm{P}_{2} \mathrm{Y}_{1}$ receptor is expressed in cornea, ciliary processes, and trabecular meshwork (16), and the $\mathrm{P}_{2} \mathrm{Y}_{2}$ receptor is expressed in cornea, ciliary processes, and retinal pigmented epithelium. $\mathrm{P}_{2} \mathrm{Y}_{4}$ and $\mathrm{P} 2 \mathrm{Y}_{6}$ receptors are present in cornea, ciliary processes, photoreceptors, and ganglion cells. $\mathrm{P} 2 \mathrm{Y}_{11}$ receptor is expressed in the retinal pigmented epithelium. Of these, $\mathrm{P} 2 \mathrm{Y}_{1}(17,18), \mathrm{P}_{2} \mathrm{Y}_{2}(19)$, and $\mathrm{P} 2 \mathrm{Y}_{6}$ receptors (20) have been shown to control IOP; however, it is unclear how these receptors control IOP and what the pathophysiological consequence of their dysregulation is. In the present study, we report that the $\mathrm{P}_{2} \mathrm{Y}_{6}$ receptor is responsible for IOP reduction and that its dysfunction causes hypertensive glaucoma-like optic neuropathy. 
A

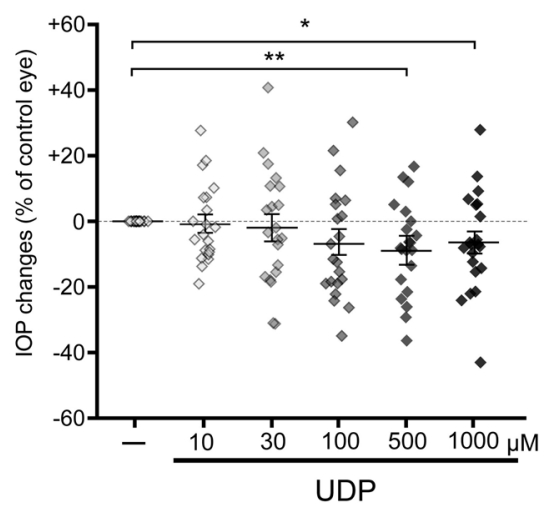

C

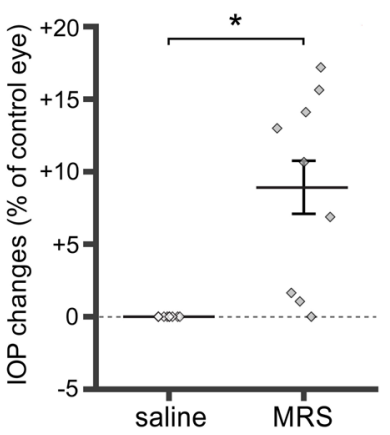

B

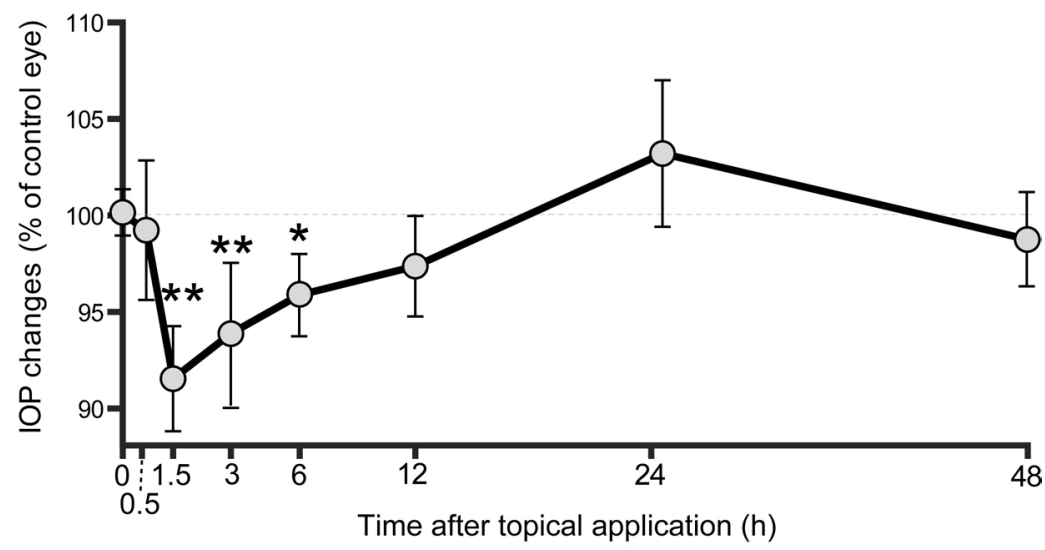

D

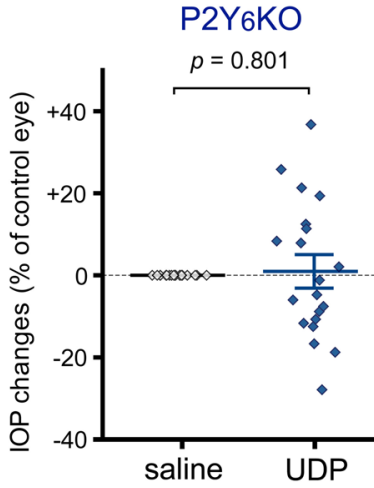

Figure 1. $\mathbf{P 2} \mathbf{Y}_{6}$ receptor activation reduces intraocular pressure. (A) Concentration dependency of the intraocular pressure (IOP) lowering effect by instillation of uridine diphosphate (UDP) in 3-month-old WT mice. UDP (1.5 h) showed a concentration-dependent IOP lowering effect, and the maximum effect was obtained at $500 \mu \mathrm{M}\left(n=20,{ }^{*} P<0.01\right.$ and ${ }^{*} P<0.05$ vs. saline-treated eyes, 1 -way ANOVA followed by Fisher's least significant difference [LSD] test). (B) Time dependency of the effect of UDP on WT mice. UDP $(500 \mu \mathrm{M})$ showed no IOP changes at 30 min but induced a maximum IOP changes at 1.5 hours, followed by gradual recovery. Statistically significant effects were obtained at $1.5-6.0$ hours $\left(n=20,{ }^{* *} P<0.01\right.$ and ${ }^{*} P<0.05$ vs. initial IOP value, 1-way ANOVA followed by Fisher's LSD test). The IOP at 24 hours showed a tendency to be elevated and recovered to the initial level at 48 hours. (C) The effect of an antagonist for P2Y ${ }_{6}$ receptor on IOP of WT mice. MRS2578 $(30 \mu \mathrm{M}, 1.5 \mathrm{~h})$, a selective antagonist for P2Y ${ }_{6}$ receptors, increased the IOP $(n=10$, ${ }^{*} P<0.05$, Mann-Whitney $U$ test). (D) The UDP effect in 3-month-old P2Y receptor-deficient (P2Y KO) mice. UDP (500 $\mu \mathrm{M}, 1.5 \mathrm{~h}$ ) did not change the IOP in $\mathrm{P} 2 \mathrm{Y}_{6} \mathrm{KO}$ mice $(n=20, P=0.801$, Mann-Whitney $U$ test). Data are shown as means $\pm \mathrm{SEM}$.

\section{Results}

$P 2 Y_{6}$ receptor activation reduces $I O P$. We investigated the physiological role of $\mathrm{P} 2 \mathrm{Y}_{6}$ receptor on IOP. Instillation of uridine diphosphate (UDP) (5 $\mu$ //eye, 1.5 hours), an endogenous agonist for $\mathrm{P}_{2} \mathrm{Y}_{6}$ receptor, caused IOP reduction of 3-month-old WT mice in a concentration-dependent manner (Figure 1A). At $500 \mu \mathrm{M}$, UDP showed the maximum effect of a $10 \%$ reduction of IOP. Significant IOP reduction by UDP was obtained at 1.5-6 hours after its application, and the maximum effect was obtained at 1.5 hours after application (Figure 1B). The IOP was then slightly increased at 24 hours and returned to the basal level at 48 hours after the instillation. In contrast to the agonist, MRS2578 (5 $\mu \mathrm{l}$ /eye at $30 \mu \mathrm{M}, 1.5$ hours), a selective antagonist for the P2Y receptor, increased IOP (Figure 1C) to approximately 10\%, similar to the maximum efficacy observed for UDP. In P2ry6-KO mice (P2Y KO mice), no IOP-lowering effect by UDP was observed (Figure 1D). These data demonstrate that UDP applied topically to eyes reduces IOP transiently under physiological conditions.

$P 2 Y_{6}$ receptor is expressed in the $C B$. Because IOP is controlled by production of the aqueous humor in the $\mathrm{CB}$ (21) and by draining via the trabecular meshwork/Schlemm's canal, plus the uveoscleral pathway (22), we investigated their expression patterns. In situ hybridization and immunofluorescence staining revealed that the P2Y ${ }_{6}$ receptor was expressed in nonpigmented epithelial cells (NPE cells) of the CB (Figure 2, A and $\mathrm{B}$ ), indicating a potential role of the $\mathrm{P}_{2} \mathrm{Y}_{6}$ receptor in controlling the dynamics of the aqueous humor.

$P 2 Y_{6}$ receptor controls the dynamics of the aqueous humor. To analyze the dynamics of the aqueous humor, we employed fluorophotometry using 2 different methods: i.p. injection (Supplemental Figure $1 \mathrm{~A}$, referred to as Fph-A; supplemental material available online with this article; https://doi.org/10.1172/jci.insight.93456DS1) 
A

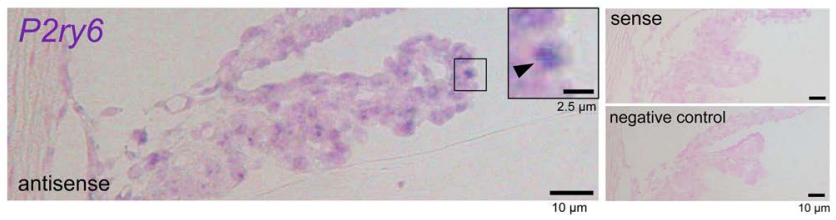

B

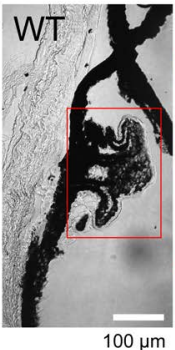

$\mathrm{P} 2 \mathrm{Y}_{6} \mathrm{R} / \mathrm{DAP}$
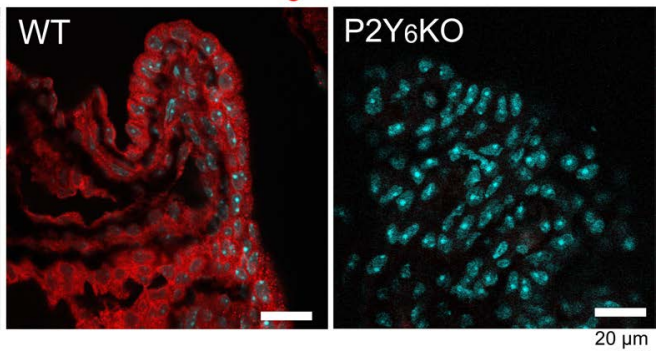

Figure 2. Expression patterns of $\mathbf{P 2 Y}_{6}$ receptors in the ciliary body. (A) In situ hybridization of ciliary bodies from ICR mice. Signals for P2ry6 mRNA (purple) were localized in the surface layer of the ciliary body (arrowhead). No purple signals were observed in samples hybridized with a sense probe (right upper panel) or without a probe (right lower panel). For counterstaining, nuclear fast red (Kernechtrot) was used. (B) Immunofluorescence staining of the expression patterns of $\mathrm{P} 2 \mathrm{Y}_{6}$ receptor in the ciliary body. $\mathrm{P} 2 \mathrm{Y}_{6}$ receptor signals (shown as red) were observed on the surface layer of the ciliary body. Data are shown as means \pm SEM. Scale bars: 2.5 (A, insert), 10 (A), 20 (B, fluorescent images) and $100 \mu \mathrm{m}$ (B, left panel).

or topical application of sodium fluorescein (Supplemental Figure 1B, referred to as Fph-B). In these analyses, a CCD camera was placed above the mouse, and the iris was not dilated (Supplemental Figure 1C). In this arrangement, fluorescent changes in the anterior chamber can be imaged (Figure 3A). Under these conditions, fluorescent levels in the anterior chamber were significantly increased during monitoring for 30 minutes. Although systemically or i.v.-injected fluorescein is usually used for fluorescent angiography, we did not observe dye leakage from retinal vessels (data not shown). The aqueous humor, isolated by piercing the cornea, showed a significant increase in fluorescence levels. The fluorescent intensities of isolated aqueous humor at 5 and 30 minutes were 200\% (Supplemental Figure 1D) and 1,500\% (Supplemental Figure 1E) of the initial levels, respectively. When we performed time-lapse imaging of WT mice using the Fph-A model, the fluorescence intensity was constantly increased and reached $300 \%$ of the initial level at 30 minutes after injection (Figure 3B). Instillation of UDP $(5 \mu 1 /$ eye at $500 \mu \mathrm{M})$ at 30 minutes before the fluorescein injection significantly suppressed the increase in fluorescence. Timolol ( $5 \mu 1 /$ eye at $0.5 \%, 30 \mathrm{~min})$, a $\beta$ blocker, also suppressed the increase in fluorescence (Figure $3 \mathrm{C}$ ). Latanoprost ( $5 \mu \mathrm{l}$ /eye at $0.005 \%$ ), a prostaglandin $\mathrm{F}_{2 \alpha}$ analogue, did not suppress the fluorescence changes in Fph-A (Figure 3, D and E). The speed of fluorescence increase was significantly enhanced in $\mathrm{P}_{2} \mathrm{Y}_{6} \mathrm{KO}$ mice ( $>400 \%$ at $30 \mathrm{~min}$ ) (Figure $3 \mathrm{~F}$ ). The suppression by UDP disappeared in $\mathrm{P}_{2} \mathrm{Y}_{6} \mathrm{KO}$ mice (Figure 3, G and H). In contrast, the Fph-B model showed an approximate $20 \%$ reduction in fluorescence intensity of the anterior chamber during 30-minute monitoring (Supplemental Figure 1, F and G). For Fph-B, latanoprost significantly enhanced the reduction in fluorescence (Figure 3, I and J). In contrast, both UDP and timolol showed no suppressive effects (Figure 3J and Supplemental Figure 1G). We did not find any effect caused by a deficiency of $\mathrm{P} 2 \mathrm{Y}_{6}$ receptor on Fph-B (Figure 3J). These data suggest that $\mathrm{P} 2 \mathrm{Y}_{6}$ receptor activation modifies the dynamics of the aqueous humor in a similar way to timolol. If $\mathrm{P} 2 \mathrm{Y}_{6} \mathrm{KO}$ mice showed sustained changes in aqueous humor dynamics, their IOP should be changed. As suspected, P2Y KO mice exhibited elevated IOP compared with WT mice at the ages of 3,6,12, and 18 months (Figure 3K). Because the $\mathrm{P}_{2} \mathrm{Y}_{6}$ receptor is expressed also in the cornea (16) and many IOP measurement methods for humans have been reported to be affected by central corneal thickness (CCT), we evaluated CCT and structural abnormalities of the cornea. We did not find any structural abnormalities (Supplemental Figure 2A) or thicknesses of the cornea (Supplemental Figure $2 \mathrm{~B}$ ) in mature adult mice (3 months old). In middle-aged mice (12 months old), the CCTs of WT and P2 ${ }_{6} \mathrm{KO}$ mice were both increased (Supplemental Figure 2B). The middle-aged P2 ${ }_{6} \mathrm{KO}$ mice showed a thicker CCT than that of the middle-aged WT mice. No obvious structural abnormalities of the cornea were observed in middle-aged WT or $\mathrm{P} 2 \mathrm{Y}_{6} \mathrm{KO}$ mice.

P2Y KO mice show histological abnormalities at middle age. Elevated IOP is one of the highest risk factors for glaucoma $(3,4)$; therefore, we determined whether $\mathrm{P} 2 \mathrm{Y}_{6} \mathrm{KO}$ mice had histological abnormalities related to glaucoma. Because axonal damage is one of the first histological changes in glaucoma, we investigated the axonal structure using serial block-face scanning electron microscopy (SBF-SEM) (Figure 4A, asterisks). To obtain detailed ultrastructural information, we collected a large number of serial images of the optic nerve (Figure 4B). SBF-SEM did not show substantial abnormalities, such as axonal swelling or 
A

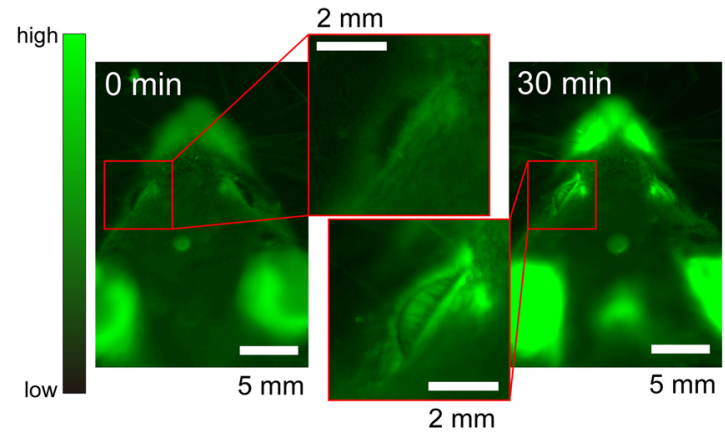

B

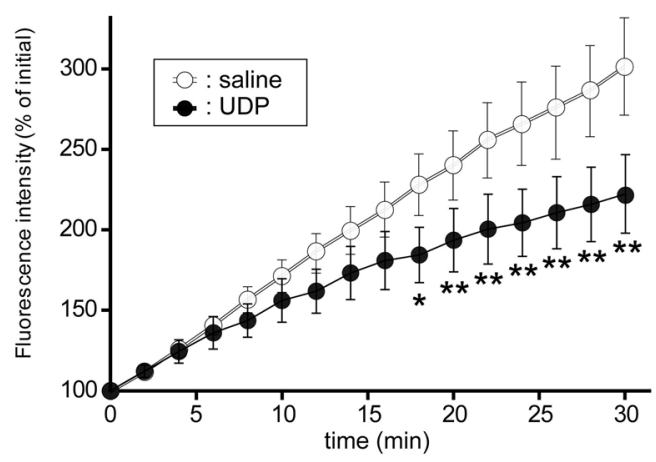

C

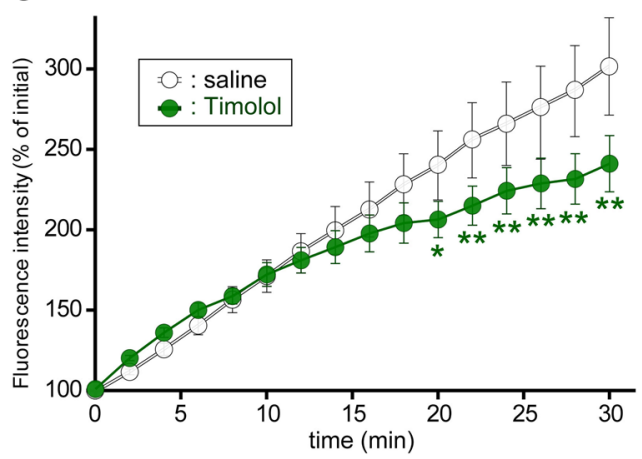

$\mathbf{F}$

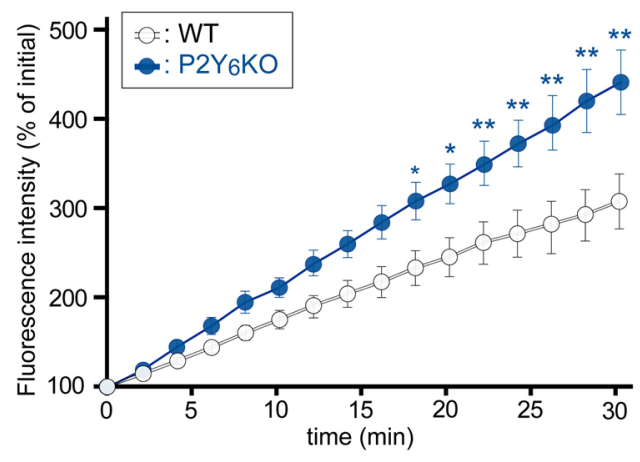

I

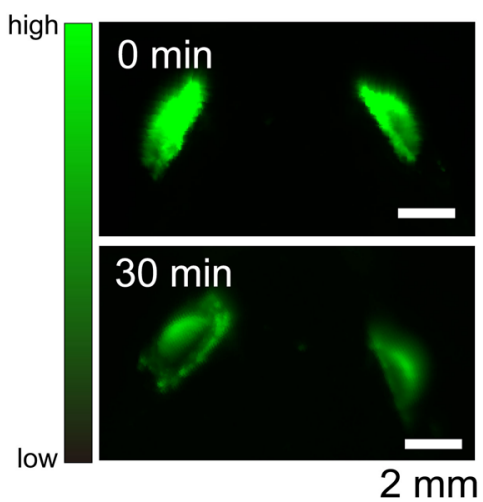

D

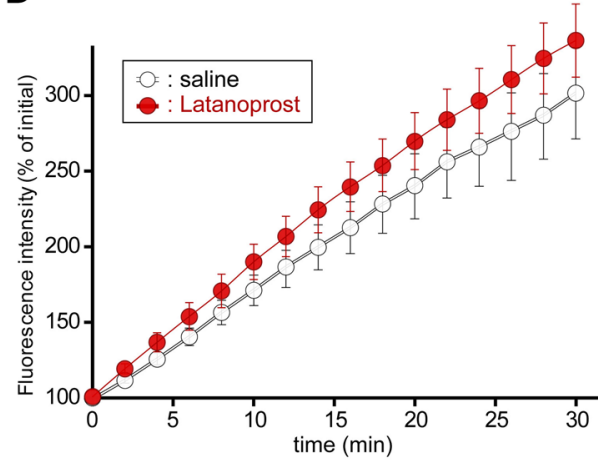

G

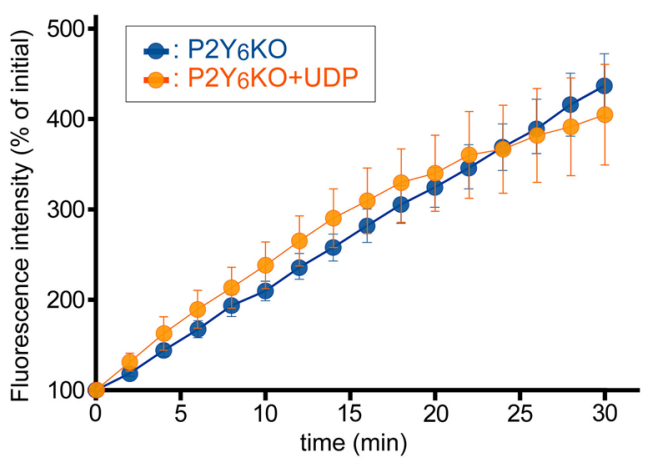

E

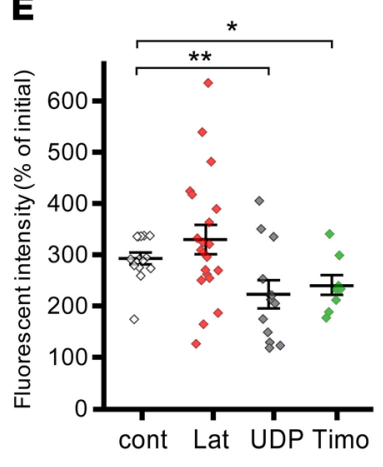

H

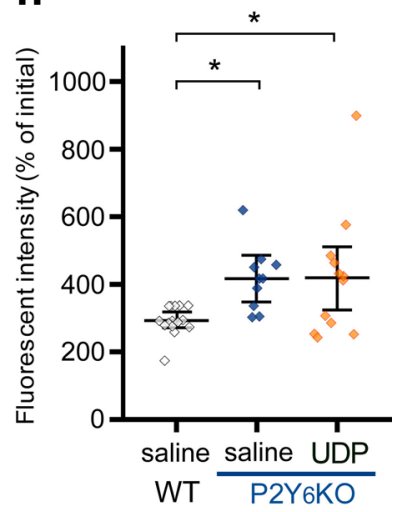

$\mathbf{K}$

$\mathbf{J}$

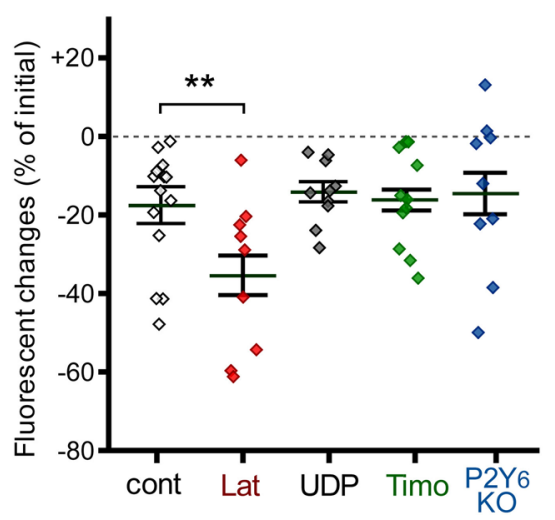

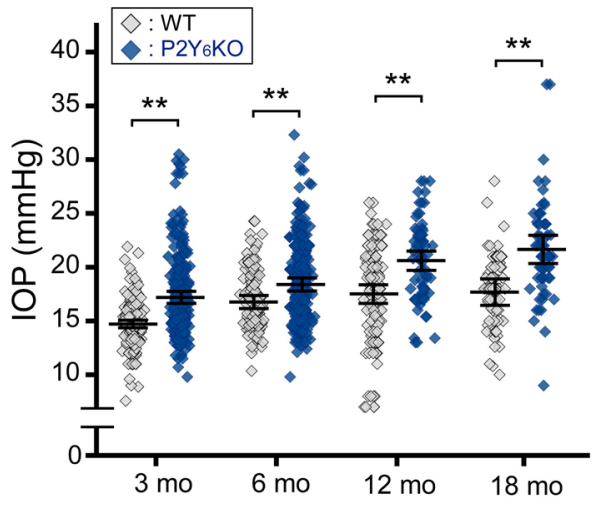

Figure 3. Aqueous humor dynamics. (A) Fluorophotometry model A (Fph-A). I.p.-injected fluorescein concentrated in the anterior chamber. (B-D) Time courses of fluorescent changes in the anterior chamber. (B) UDP and (C) timolol reduced the fluorescein influx rate, but (D) latanoprost did not $(n=10-21$, ${ }^{*} P<0.01$ vs. control, 2-way repeated ANOVA followed by Fisher's LSD test). (E) Quantitative data for fluorescence intensity at 30 minutes ( $n=10-21,{ }^{*} P$ $<0.05,{ }^{*} P<0.01$ vs. control, 1-way ANOVA followed by Fisher's LSD test). (F) P2Y ${ }_{6}$ KO mice showed enhanced fluorescein influx, and (G) no UDP effects 
were observed. (H) Quantitative data at 30 minutes of F and G ( $n=10-16,{ }^{*} P<0.05$ vs. control, 1-way ANOVA followed by Fisher's LSD test). (I) Representative images of latanoprost-treated eyes in the Fph-B model. Significant reduction in fluorescence intensity was observed at 30 minutes. (J) Fluorescein draining was significantly enhanced by latanoprost but not by UDP or timolol, or in P2Y KO mice $\left(n=10-18\right.$, ${ }^{* *} P<0.01$ vs. control, 1 -way ANOVA followed by Bonferroni correction). (K) IOP levels were significantly higher compared with those of WT mice ( $n=61-318$, ${ }^{*} P<0.01$, Bonferroni correction). Data are shown as means \pm SEM. Scale bars: 2 (A, inserts, and I) and $5 \mathrm{~mm}(\mathbf{A})$.

accumulation of axoplasmic organelles in 3-month-old WT, 3-month-old P2Y KO, and 12-month-old WT mice (Figure 4C). However, the 12-month-old $\mathrm{P} 2 \mathrm{Y}_{6} \mathrm{KO}$ mice showed prominent axonal swelling with axoplasmic organelle accumulation in the optic nerve (Figure $4 \mathrm{C}$, arrows).

We then analyzed histological changes in the retina using optical coherence tomography (OCT). We estimated the thickness of ganglion cell plus inner plexiform layers (GCL/IPL) because the thinning of these layers is correlated with the loss of visual function in glaucoma patients (23-25) and experimental glaucoma model in primates $(26,27)$. Tomographic images were obtained from around the optic nerve head (indicated as a green circle in the upper panels of the OCT images in Figure 4D). WT mice showed no significant changes in the thickness of GCL/IPL among 3-, 6-, and 12-month-old mice (Figure 4D). Three-month-old P2Y ${ }_{6} \mathrm{KO}$ mice had a similar GCL/IPL thickness with WT mice, but 6- and 12-month-old P2Y ${ }_{6} \mathrm{KO}$ mice had a significantly thinner GCL/IPL. The other retinal layers, including the outer plexiform layer (OPL), outer nuclear layer (ONL), external limiting membrane (ELM), and inner/outer segment (IS/ OS), showed no structural abnormalities by OCT (Supplemental Figure 3A). We did not find any significant abnormalities in the structure of the $\mathrm{CB}$ or anterior chamber (including the trabecular meshwork and Schlemm's canal) in P2Y KO mice (Supplemental Figure 3B). Next, we performed the quantitative analysis of RGC damage by immunofluorescence staining. There was no difference in the number of BRN3A ${ }^{+}$ RGCs in 3- to 12-month-old WT mice (Figure 4E). In 3-month-old P2Y ${ }_{6} \mathrm{KO}$ mice, the number of BRN3A ${ }^{+}$ RGCs was similar to that of WT mice. P2Y $\mathrm{KO}$ mice at 6 and 12 months old showed a significant reduction in RGC numbers.

We then evaluated whether RGC damage in P2Y $\mathrm{KO}$ mice was caused by sustained IOP elevation or by a deficiency of the $P 2 r y 6$ gene. Lowering IOP using a topical agent prevents or delays vision loss $(3,4)$; therefore, we used latanoprost to reduce IOP levels in P2 $\mathrm{Y}_{6} \mathrm{KO}$ mice. Daily administration of latanoprost $(0.005 \%, 5 \mu 1 /$ eye/day, from 1-6 months old) reduced IOP levels of P2Y KO mice to the level of 6-monthold WT mice (Figure 5A). Under this condition, the reduced GCL/IPL thickness (Figure 5B) and RGC numbers (Figure 5, C and D) were restored. Thus, our data show that the sustained elevation of IOP is a cause of RGC degeneration in $\mathrm{P}_{2} \mathrm{Y}_{6} \mathrm{KO}$ mice.

Impaired visual function in $P 2 Y_{6} K O$ mice. Because the degeneration of RGCs is a primary cause of blindness in glaucoma, we tested the visual function of $\mathrm{P}_{2} \mathrm{Y}_{6} \mathrm{KO}$ mice using multifocal electroretinograms (mfERGs). Four-month-old WT, 4-month-old $\mathrm{P}_{2} \mathrm{Y}_{6} \mathrm{KO}$, and 13-month-old WT mice showed no significant dysfunction, whereas 13-month-old P2Y $\mathrm{KO}$ mice showed significantly impaired visual function (Figure 6). Taken together, these findings indicate that middle-aged but not mature adult $\mathrm{P} 2 \mathrm{Y}_{6} \mathrm{KO}$ mice have disordered visual function.

Downregulation of $\mathrm{P} \mathrm{Y}_{6}$ receptors in WT mice with age. We evaluated whether such impairments of the $\mathrm{P} 2 \mathrm{Y}_{6}$ receptor occur naturally in the eye. Because aging is another key risk factor for pathogenesis of glaucoma (28-31), we investigated whether aging affects $\mathrm{P}_{2} \mathrm{Y}_{6}$ receptor levels and/or functions. We evaluated retinal P2ry6 mRNA levels and found that retinae from WT mice at 6-12 months old had significantly lower P2yr6 mRNA levels compared with 1- to 3-month-old WT mice (Supplemental Figure 4A). This result was in accord with a previous study (32). Because it was difficult to isolate $\mathrm{CB}$, we estimated the expression level of P2Y 6 receptor in the $\mathrm{CB}$ by immunofluorescence staining. Fluorescence signals for $\mathrm{P} 2 \mathrm{Y}_{6}$ receptor were detected in the CB (Supplemental Figure 4B), and the signal intensity in 12-month-old WT mice reduced by 50\% compared with 3-month-old WT mice. Because the layered pattern of $\mathrm{P}_{2} \mathrm{Y}_{6}$ receptor signals correspond with NPE cells, we examined $\mathrm{P}_{2} \mathrm{Y}_{6}$ receptor functions by $\mathrm{Ca}^{2+}$ imaging. Isolated ciliary bodies/sclera from mature adult WT mice were sliced by a tissue chopper and plated on a culture dish. Pigmented epithelial cells (PE cells) can be identified by the pigment in their cytoplasm. UDP $(100 \mu \mathrm{M})$ evoked clear intracellular calcium concentration ([Ca $\left.{ }^{2+}\right]$ i) transients in NPE cells (Supplemental Figure 4C) but not in PE cells (Supplemental Figure 4D). UDP-evoked $\left[\mathrm{Ca}^{2+}\right]$ i responses were abolished in the presence of MRS2578 (3 $\left.\mu \mathrm{M}\right)$ (Supplemental Figure 4E), indicating that functional $\mathrm{P} 2 \mathrm{Y}_{6}$ receptor is expressed in NPE cells. The $\mathrm{Ca}^{2+}$ responses in NPE cells were significantly reduced when they were isolated from 12-month-old WT mice (Supplemental Figure 4, F and G). We determined whether the reduction in $\mathrm{P}_{2} \mathrm{Y}_{6}$ receptor-mediated responses contributed to the effectiveness of 
A
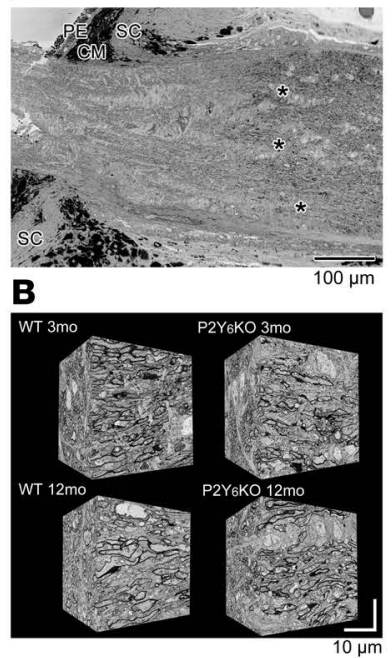

C
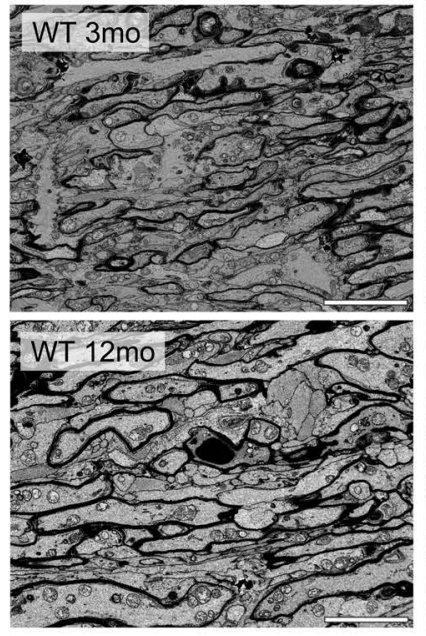
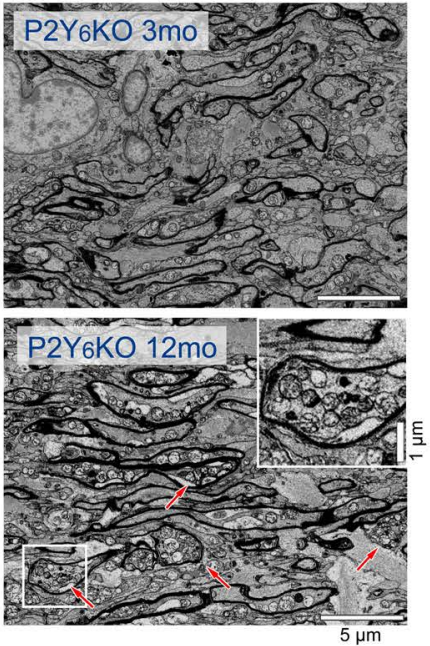

D
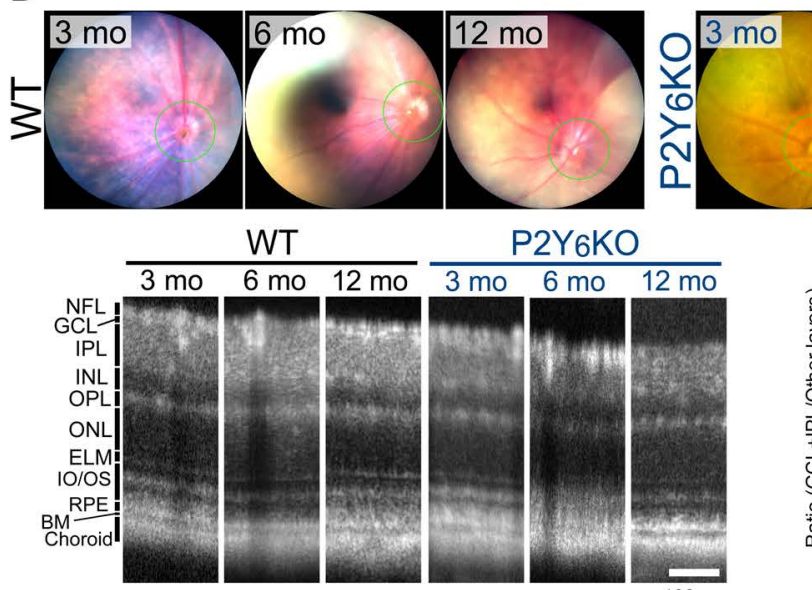

P2Y6KO
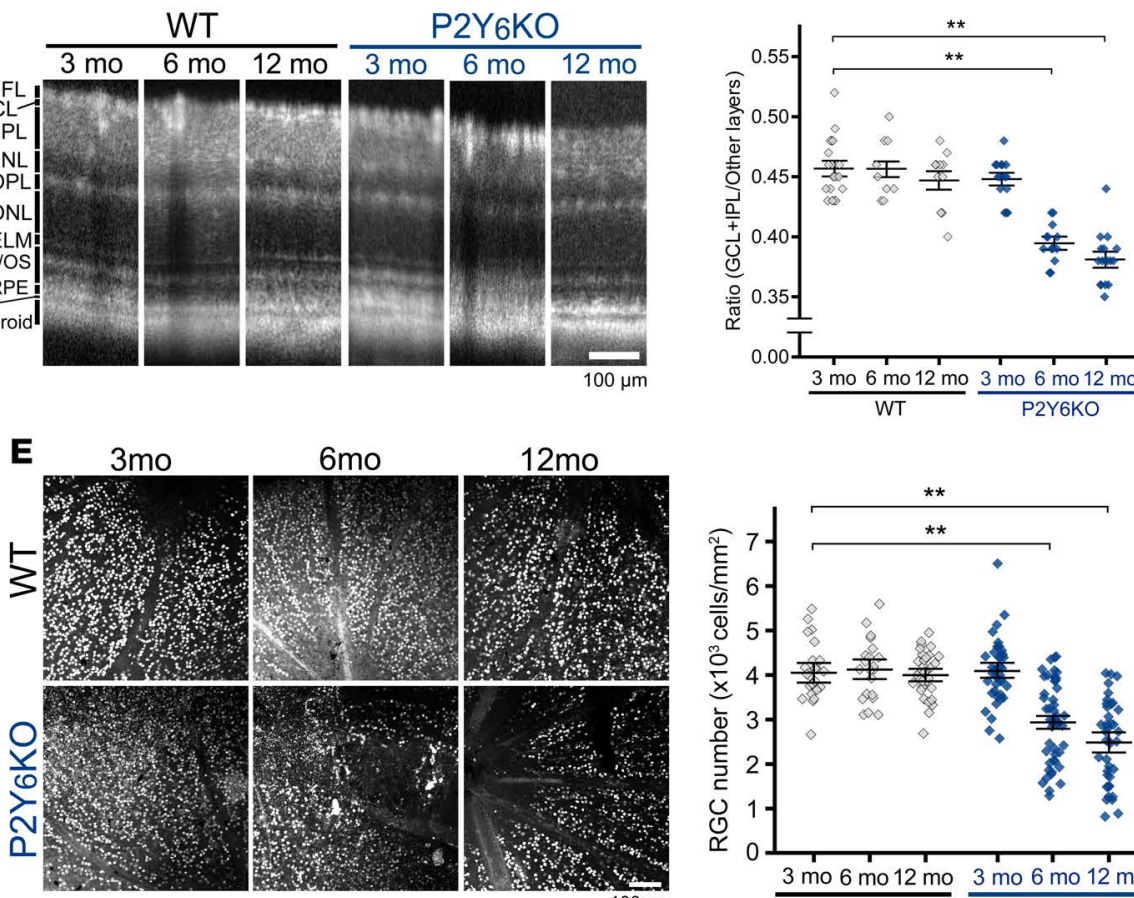

6 mo

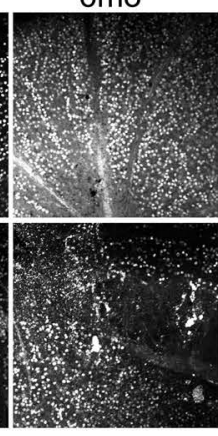

$12 \mathrm{mo}$

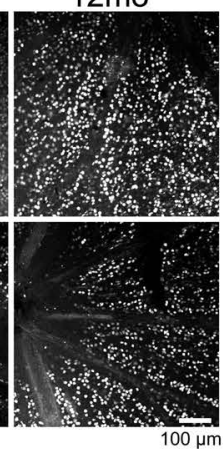

Figure 4. Histological changes in $\mathrm{P2Y}_{6} \mathbf{K O}$ mice. (A) Serial blockface scanning electron microscopy (SBF-SEM) analysis of optic nerve structures. Images were obtained from the distal part of the axon where myelination starts (asterisks), and (B) serial images were obtained for detailed ultrastructural analyses. (C) Serial images from mature adult (3 months old) WT and P2Y $\mathrm{K}_{6} \mathrm{KO}$ mice showed no substantial structural abnormalities, such as axonal swelling or accumulation of axoplasmic organelles. In contrast, middle-aged P2Y ${ }_{6} \mathrm{KO}$ - but not WT mice (12 months old) - showed prominent axonal swelling with axoplasmic organelle accumulation in the optic nerve (arrows). (D) Representative tomographic images obtained by optical coherence tomography (OCT). Coronary images were obtained around the optic nerve head (green circles in upper panels). WT mice showed no significant changes in retinal cell layer structures regardless of age. $\mathrm{P}_{2} \mathrm{Y}_{6} \mathrm{KO}$ mice showed age-dependent reduction in total ganglion cell layer (GCL) and inner plexiform layer (IPL) area $(n=16,9$, and 13 , for WT at 3,6 , and 12 months of age, respectively, and $n=15,15$, and 16 for $\mathrm{P} 2 \mathrm{Y}_{6} \mathrm{KO}$ at 3,6 , and 12 months of age, respectively. ${ }^{*} P<$ 0.01 vs. WT, 1-way ANOVA followed by Fisher's LSD test). (E) Immunofluorescence staining for detecting retinal damages. Retinal ganglion cells (RGCs) were visualized with an anti-brain-specific homeobox/POU domain protein 3 A (BRN3A) antibody in whole-mounted retinas and counted. No significant reduction in RGC number was observed in WT mice, whereas P2Y ${ }_{6} \mathrm{KO}$ mice showed an age-dependent decrease $(n=25$, ${ }^{*} P<0.01$ vs. WT, 1-way ANOVA followed by Fisher's LSD test). Scale bars: 1 (C, insert), 5 (C), 10 (B), 100 (A, D [OCT images], and $\mathbf{E})$, and $250 \mu \mathrm{m}$ (D, fundus images).

UDP-induced IOP lowering. Instillation of UDP ( $500 \mu \mathrm{M}, 5 \mu \mathrm{l}$ /eye for 1.5 hours) in 12-month-old WT mice still reduced the IOP (Supplemental Figure $4 \mathrm{H}$ ), but the efficacy was reduced to about $50 \%$ of that in 3-monthold WT mice $(4.6 \% \pm 3.0 \%$ and $10.1 \% \pm 2.8 \%$ for 3 - and 12 -month-old mice, respectively).

\section{Discussion}

We report that the $\mathrm{P} 2 \mathrm{Y}_{6}$ receptor is essential for regulating the IOP, and deficiency of this gene causes elevated IOP and hypertensive glaucoma-like phenotypes, including degeneration of the optic nerve and RGCs and dysregulated visual functions. Regarding the mechanism involved in IOP reduction, the $\mathrm{P}_{2} \mathrm{Y}_{6}$ receptor in the NPE cells suppressed the production of aqueous humor from the CB. 
A

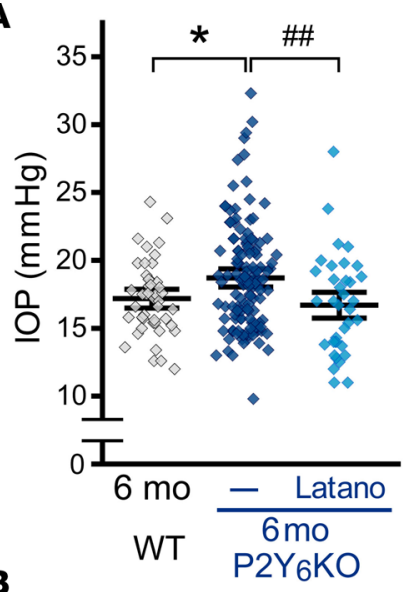

Figure 5. Reduction of IOP prevents RGC damage. (A) Daily topical administration of latanoprost to $\mathrm{P} 2 \mathrm{Y}_{6} \mathrm{KO}$ mice over 4 months reduced the basal IOP to that of WT mice $\left(n=10-20,{ }^{*} P<0.05\right.$ vs. WT 6 months, ${ }^{\# \#} P<0.01$ vs. P2Y ${ }_{6}$ KO 6 months, 1-way ANOVA followed by Fisher's LSD test). (B) Thinning of ganglion cell layer and inner plexiform layer (GCL/IPL) in 6-month-old P2Y ${ }_{6} \mathrm{KO}$ mice observed by OCT was restored by daily latanoprost administration ( $n=10-20,{ }^{*} P<0.05,{ }^{* *} P<0.01$ vs. WT 6 months, ${ }^{\# \# P}<0.01$ vs. P2Y $\mathrm{Y}_{6} \mathrm{KO}$ 6 months, 1-way ANOVA followed by Fisher's LSD test). (C and D) Latanoprost prevented the reduction in RGC number in 6-month-old P2Y ${ }_{6} \mathrm{KO}$ mice $(n=25$, ${ }^{*} P<0.01$ vs. WT 6 months, ${ }^{\# \#} P<0.01$ vs. P2Y ${ }_{6}$ KO 6 months, 1-way ANOVA followed by Fisher's LSD test). Values are the mean \pm SEM. Scale bars: 100 $\mu \mathrm{m}$ in $\mathbf{B}$ and $\mathbf{C}, 250 \mu \mathrm{m}$ in $\mathbf{B}$.

\section{B}
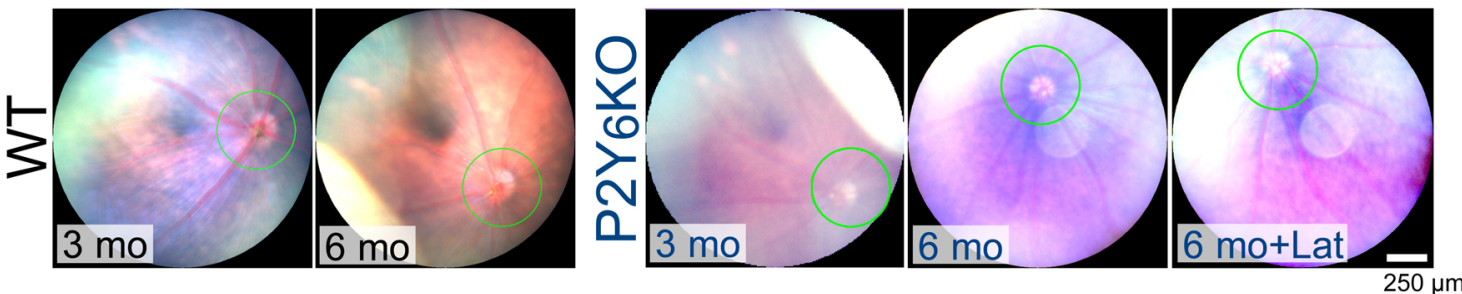
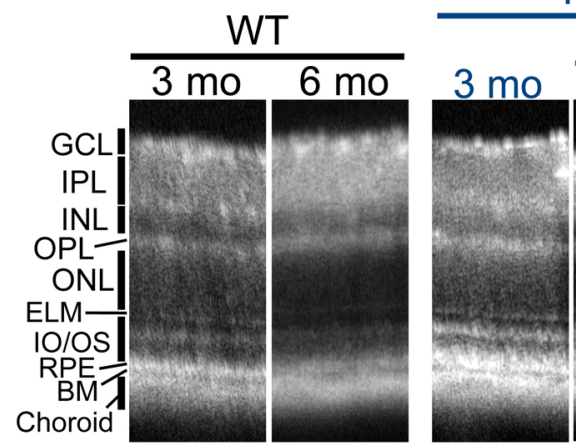

P2Y6KO

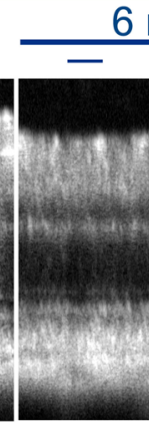

C

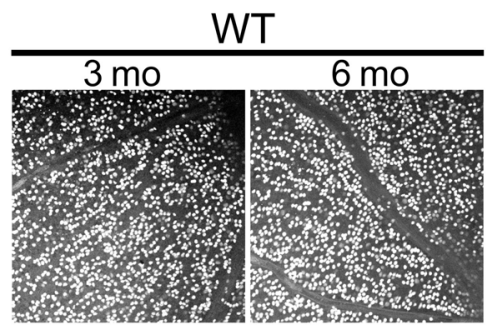

P2Y6KO

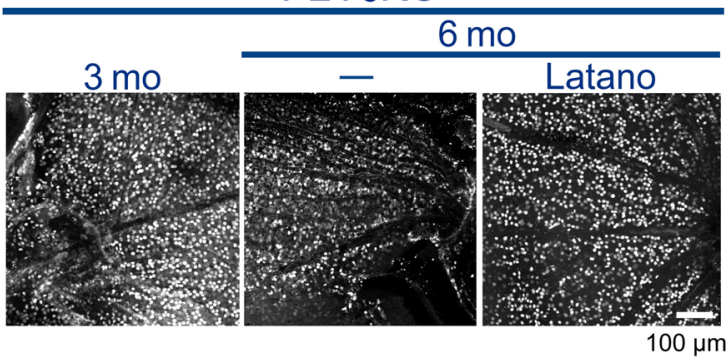

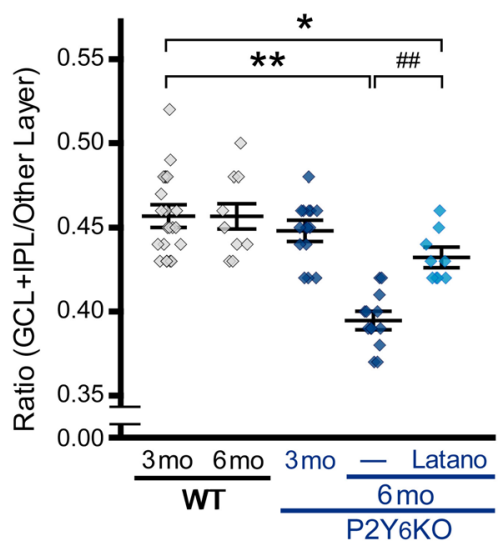

D

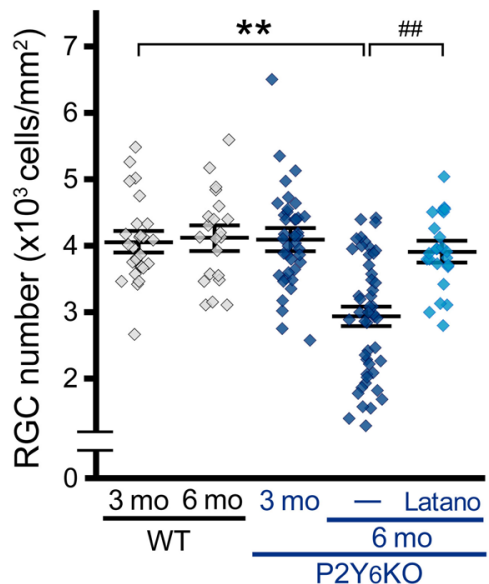



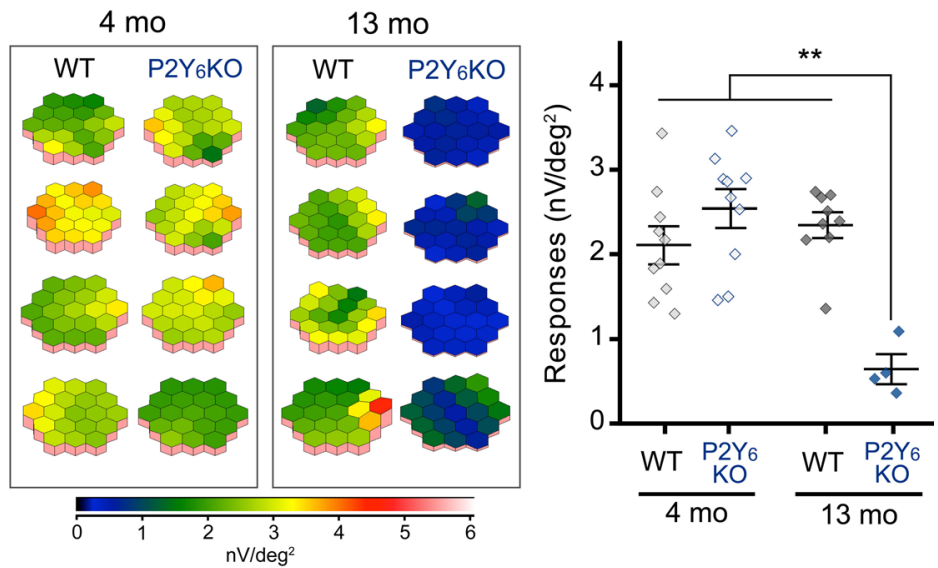

Figure 6. $\mathbf{P 2 Y}_{6} \mathrm{KO}$ mice show visual dysfunction. Impaired visual function estimated by multifocal electroretinogram (mfERG). Representative $2 \mathrm{~K}$ responses are shown in the left panels. Three-dimensional plots show the amplitude variation across the arrays. Quantitative data showed no differences in ERG responses in mature adult mice but a significant reduction in middle-aged $\mathrm{P} 2 \mathrm{Y}_{6} \mathrm{KO}$ mice ( $n=10$ and 10 for WT at 4 and 13 months of age, respectively, and $n$ $=9$ and 4 for P2Y $\mathrm{KO}$ at 4 and 13 months of age, respectively. ${ }^{* *} \mathrm{P}<$ $0.01,1$-way ANOVA followed by Fisher's LSD test). Data are shown as means $\pm \mathrm{SEM}$.

Nucleotides have been reported to be present in the aqueous humor (33) and released from various eye tissues and cells $(9,34-37)$ in response to physiological stimuli; for example, physiological IOP elevation evokes exocytotic ATP release from the CB $(12,38)$. Pintor's group has extensively studied nucleotide-mediated IOP changes (18-20, 39), and our data showing a hypotensive UDP effect was consistent with their results. In addition to the physiological roles of extracellular nucleotides, intraocular nucleotide levels have been reported to be elevated in the aqueous humor of glaucoma patients $(13,14,40)$, indicating the pathological roles of dysregulated purinergic signaling in glaucoma. However, before this study, it was unclear whether the dysregulation of purinergic signaling contributed to the pathogenesis of glaucoma.

Histological analysis revealed that $\mathrm{P}_{2} \mathrm{Y}_{6}$ receptors are localized in NPE cells and stroma of the ciliary processes, similar to a previous report (16). Indeed, $\mathrm{Ca}^{2+}$ imaging showed that primary cultured NPE cells, but not PE cells, clearly responded to UDP. Because the CB mediates aqueous humor production, we used fluorophotometry with a minor modification to investigate the role of the P2Y receptor. We used 2 conditions including Fph-A and -B. The Fph-A model showed a linear fluorescence increase in the anterior chamber, which was suppressed by UDP or timolol but not by latanoprost. P2Y KO mice showed an accelerated fluorescence increase, which was not inhibited by UDP. In contrast, the Fph-B model showed a fluorescent reduction, which was enhanced by latanoprost but not by UDP, timolol, or P2Y KO. Thus, we concluded that $\mathrm{P}_{2} \mathrm{Y}_{6}$ receptor controls the dynamics of the aqueous humor in a similar way to timolol. Because timolol suppresses the production of the aqueous humor (41-44), the mechanism involving P2Y receptors might be mediated by a similar mechanism. If this is true, how does the $\mathrm{P}_{2} \mathrm{Y}_{6}$ receptor control the production of the aqueous humor? Transepithelial $\mathrm{Cl}^{-}$transport across the ciliary epithelium was reported to produce the driving force for aqueous humor formation (45-50). $\mathrm{Cl}^{-}$secretion from NPE cells is mediated by $\mathrm{Cl}^{-}$channels, whose activity is controlled by intracellular cyclic adenosine monophosphate (cAMP), which is increased by $\mathrm{P}_{2} \mathrm{Y}_{6}$ receptor activation $(51,52)$. It has been reported that cAMP causes both an increase (52-54) and decrease of $\mathrm{Cl}^{-}$secretion (55-57). One explanation for these controversial reports might be related to TGF $\beta$-mediated mechanisms. TGF $\beta$ reverses cAMP-mediated $\mathrm{Cl}^{-}$channel activation (58). Because P2 ${ }_{6}$ receptor activation causes TGF $\beta$ production $(59,60)$, UDP may suppress $\mathrm{Cl}^{-}$secretion by producing both TGF $\beta$ and cAMP. Another possible candidate is the gap junction because it mediates intercellular connections between PE and NPE cells, which is essential for transepithelial $\mathrm{Cl}^{-}$transport $(56,61)$. Elevation of cAMP caused intercellular uncoupling between PE and NPE cells (56). Elevated $\left[\mathrm{Ca}^{2+}\right] \mathrm{i}$ also induced the uncoupling of gap junctions (62-64). $\mathrm{P}_{2} \mathrm{Y}_{6}$ receptor activation may suppress transepithelial $\mathrm{Cl}^{-}$transport via the uncoupling of PE and NPE cells by the elevation of cAMP and [ $\left.\mathrm{Ca}^{2+}\right]$ i. In addition to NPE cell-mediated mechanisms, $\mathrm{P} 2 \mathrm{Y}_{6}$ receptors are localized in the stroma of the ciliary process (16). As discussed in a previous study (20), because $\mathrm{P} 2 \mathrm{Y}_{6}$ receptors in blood vessels cause vasoconstriction $(65,66)$, the hypotensive effect by $\mathrm{P}_{2} \mathrm{Y}_{6}$ receptors may be in part induced by vasoconstriction. These reports suggest that $\mathrm{P}_{2} \mathrm{Y}_{6}$ receptor may suppress the production of the aqueous humor via multiple mechanisms.

Accelerated formation of the aqueous humor in $\mathrm{P} 2 \mathrm{Y}_{6} \mathrm{KO}$ mice suggested that IOP levels should be altered in these mutant mice. Indeed, $\mathrm{P}_{2} \mathrm{Y}_{6} \mathrm{KO}$ mice showed a sustained elevation of IOP. CCT measurement revealed that $\mathrm{P} 2 \mathrm{Y}_{6} \mathrm{KO}$ mice showed thicker CCT at middle age. Many reports have suggested that IOP is positively correlated to CCT (67-75). Our present data demonstrated that mature adult P2Y $\mathrm{KO}$ 
mice had elevated IOP compared with WT mice without differences in CCT; thus, we concluded that the elevated IOP value in mature adult $\mathrm{P} 2 \mathrm{Y}_{6} \mathrm{KO}$ mice is not caused by CCT changes but rather by changes in aqueous humor flow. In contrast, we found that the CCTs of WT and P2Y ${ }_{6} \mathrm{KO}$ mice were increased at middle age. Human data have shown that a $1-\mathrm{mmHg}$ IOP increase requires a $10-100 \mu \mathrm{m}$ increase in CCT. Our results show an increase of IOP with 2.8 (WT) and $3.4 \mathrm{mmHg}\left(\mathrm{P}_{2} \mathrm{Y}_{6} \mathrm{KO}\right)$ in 3- to 12-month-old mice. Therefore, if these IOP increments were all caused by CCT changes, the CCTs at 12 months of age should be larger with 28-280 (WT) and 34-340 mmHg (P2Y KO). Our CCT data showed increases of 6.5 (WT) and $29.4 \mu \mathrm{m}$ (P2Y $\mathrm{KO}$ ); therefore, we concluded that the age-associated IOP increase was not caused by CCT changes but mainly by the altered dynamics of the aqueous humor.

We found that $\mathrm{P} 2 \mathrm{Y}_{6} \mathrm{KO}$ mice showed structural and functional abnormalities of the retina at $>6$ months old. Structural damage was reduced by lowering IOP with the daily application of latanoprost, indicating that elevated IOP is a cause of glaucoma-like phenotypes in $\mathrm{P}_{2} \mathrm{Y}_{6} \mathrm{KO}$ mice. We also report controversial results. First, WT mice at 12-18 months of age showed elevated IOP equivalent to that of P2Y $\mathrm{KO}_{6}$ mice at 6 months. Despite the high IOP, WT mice showed no significant abnormalities. Second, P2Y KO mice at 3 months of age already showed high IOP but no structural or functional abnormalities. These results suggest that IOP is one of a number of causes of glaucoma. What is the difference between WT and P2Y KO mice? As we previously reported, the $\mathrm{P}_{2} \mathrm{Y}_{6}$ receptor is expressed in NPE cells and other cell types, including RGCs (76) and microglia (77). $\mathrm{P}_{2} \mathrm{Y}_{6}$ receptor in RGCs tonically enhances axonal function, and the KO of P2ry6 resulted in impaired axonal elongation (76). Because impaired axonal function is the first histological change in glaucoma (78), P2Y ${ }_{6}$ KO RGCs may have vulnerable axons and glaucoma-like phenotypes. P2Y 6 receptors are essential for controlling microglial functions, and they were activated in an animal glaucoma model (79) and human glaucoma patients (80). Minocycline, an inhibitor of microglia, improved the integrity of the optic nerve head in a mouse model of glaucoma without a reduction in IOP (81). These reports indicate that aberrantly activated microglia might cause RGC damage as a downstream event of P2Y receptor deficiency.

We also found that $\mathrm{P} 2 \mathrm{Y}_{6}$ receptors were downregulated in the $\mathrm{CB}$, even in middle-aged WT mice. Possible candidates for this mechanism are $\mathrm{PKC} \alpha(82)$ and prostaglandin $\mathrm{E}_{2}\left(\mathrm{PGE}_{2}\right)(83)$. Because these molecules increase with aging $(84,85)$, age-associated expression changes of $\mathrm{P}_{2} \mathrm{Y}_{6}$ receptor may be controlled by several signaling pathways. Associated with the expression level, the efficacy of UDP on IOP was also reduced in middle-aged WT mice. Thus, our data suggest that $\mathrm{P}_{2} \mathrm{Y}_{6}$ receptor function is disordered in an age-associated manner, thereby elevating IOP. Furthermore, the dysregulation of $\mathrm{P}_{2} \mathrm{Y}_{6}$ receptor function may increase the risk for the pathogenesis of glaucoma.

Taken together, our data demonstrate that $\mathrm{P} 2 \mathrm{Y}_{6}$ receptor activation changes aqueous humor dynamics, thereby reducing IOP levels. The dysregulation of $\mathrm{P} 2 \mathrm{Y}_{6}$ receptors causes sustained IOP elevation, aging-dependent RGC damage, and impairment in visual functions, which are similar to the phenotypes of hypertensive glaucoma. Therefore, the $\mathrm{P}_{2} \mathrm{Y}_{6}$ receptor is a key target for the treatment of glaucoma.

\section{Methods}

Animals. Mice were obtained from Japan SLC. P2Y ${ }_{6}$ receptor $\mathrm{KO}$ mice were generated as previously reported (86). Mice were kept at $23^{\circ} \mathrm{C}$ with a 12 -hour (6:00 am to 6:00 pm) light-dark cycle. Experiments for IOP measurement and aqueous humor dynamics were performed between 6:00 pm and 12:00 pm.

Chemicals and antibodies. Reagents were obtained from the following sources. BSA, $N, N$ '-1,4-Butanediylbis[ $N^{\prime}$-(3-isothiocyanatophenyl) thiourea (MRS2578), paraformaldehyde (PFA), Triton X-100, and UDP were purchased from Sigma-Aldrich. DAPI was obtained from Dojindo. Sodium fluorescein (1.03887.0050) was purchased from Millipore. An anti-BRN3A antibody (goat polyclonal, sc-31984) was purchased from Santa Cruz Biotechnology. P2Y 6 antibody (rabbit polyclonal, ab13391) was obtained from Abcam. Eye drops containing tropicamide (0.5\%) with phenylephrine (0.5\%) (Mydrin-P), latanoprost (0.005\%, Senju), or timolol (0.5\%, Teika) were purchased from Santen Pharmaceutical Co., Senju Pharmaceutical, and Teika Pharmaceutical, respectively.

Measurement of IOP. IOP was measured using a rebound-type tonometer (TonoLab). Mice were anesthetized with pentobarbital (i.p., $50 \mathrm{mg} / \mathrm{kg}$ ), and IOP was measured after loss of righting reflex. IOP measurement was performed following the manufacturer's protocol. The tonometer was placed $5 \mathrm{~mm}$ away from the eye at an angle of $90^{\circ}$. IOP was measured 5 times per eye, and the values were averaged. All IOP measurements were performed from $6 \mathrm{pm}$ to $12 \mathrm{pm}$. For eye drop treatment, $5 \mu \mathrm{l}$ of agents were topically applied 30 minutes before IOP measurement. 
Aqueous humor dynamics assays. Aqueous humor dynamics were measured by fluorophotometry. Mice were anesthetized with pentobarbital $(50 \mathrm{mg} / \mathrm{kg})$, and the dynamics were measured using 2 models including model A (Fph-A) and B (Fph-B). In Fph-A, sodium fluorescein $(0.2 \%, 100 \mu \mathrm{l})$ was i.p. injected into mice, and fluorescence levels in the anterior chamber were monitored by a cooled CCD camera (3.2 megapixel Fujifilm super CCD) equipped with LAS-4000 (GE Healthcare) (87) every 2 minutes. Because the IOP-lowering agents showed their maximum effect within a few hours (88), we set a test time of 30 minutes. In Fph-B, fluorescein $(0.02 \%, 5 \mu \mathrm{l})$ was topically administered for 5 minutes, followed by washing 5 times with $500 \mu \mathrm{l}$ of saline (89). UDP $(500 \mu \mathrm{M}, 5 \mu \mathrm{l})$, latanoprost $(0.005 \%, 5 \mu \mathrm{l})$, or timolol $(0.5 \%, 5 \mu \mathrm{l})$ were applied in eye drops 30 minutes before fluorescein administration. Mice were anesthetized with sodium pentobarbital (50 mg/kg, i.p.) 25 minutes after eye-drop treatment. In Fph-A, the endogenous (without fluorescein injection) fluorescence level in the anterior chamber was equivalent to the level in the first images immediately after fluorescein injection (data not shown). The fluorescence level steadily increased to $300 \%$ at 30 minutes. In Fph-B, the fluorescence level was slightly increased during the first 4-6 minutes and then decreased, consistent with a previous report (89).

Preparation of whole-mount retinas. Eyes were enucleated and immersed in 4\% of PFA for 30 minutes at room temperature and then dissected. Retinas were postfixed for 12 hours at $4^{\circ} \mathrm{C}$. Immunostained retinas were mounted with Slow Fade Gold antifade reagent (Life Technologies).

Preparation of retinal sections. Enucleated eyes were fixed in $4 \%$ of PFA for 1 day at $4^{\circ} \mathrm{C}$ and soaked in $20 \%$ and $30 \%$ sucrose/PBS for 3 hours each. The samples were then embedded in Tissue-Tek optimal cutting temperature compound (Sakura Fintechnical) and frozen. All specimens were sectioned at $20 \mu \mathrm{m}$ in the plane of the optic nerve head. For H\&E staining, tissues were embedded in paraffin.

OCT. OCT was performed using a Micron IV Retinal Imaging Microscope (Phoenix Research Labs) following the manufacturer's instructions. Mice were anesthetized with ketamine $(100 \mathrm{mg} / \mathrm{kg})$ and xylazine $(9 \mathrm{mg} / \mathrm{kg})$. Cross-sectional images of retinas were obtained from the region surrounding the optic nerve head (shown as green circles in the fundus images of Figure $4 \mathrm{D}$ and Figure 5B).

Real time RT-PCR. Total RNA was isolated and purified from astrocytes and neurons using RNeasy (Qiagen) according to the manufacturer's instructions. Reverse transcription PCR (RT-PCR) was performed using a PrimeScript One Step RT-PCR Kit (Takara Bio Inc.) according to the manufacturer's protocol. The reaction mix contained $40 \mathrm{ng}$ total RNA, $200 \mathrm{nM}$ primers, $100 \mathrm{nM}$ TaqMan probe, TAKARA EX Taq HS, and PrimeScript RT enzyme Mix. RT-PCR amplification and real-time detection were performed using an Applied Biosystems 7500 Real-Time PCR System (Applied Biosystems). The reverse transcription was performed at $42^{\circ} \mathrm{C}$ for 5 minutes, followed by inactivation at $95^{\circ} \mathrm{C}$ for 10 seconds. The temperature profile consisted of 40 cycles of denaturation at $95^{\circ} \mathrm{C}$ for 5 seconds and annealing/extension at $60^{\circ} \mathrm{C}$ for 34 seconds. Primers and the Taqman probes for mouse Gapdh (catalog 4308313) and P2ry6 (Mm02620937_s1) were obtained from Applied Biosystems.

In situ hybridization. For in situ hybridization, 8-week-old male ICR mice were used. A 581-bp DNA fragment corresponding to nucleotide positions 11-591 of mouse P2ry6 (GenBank accession number NM_183168.2) was subcloned into pGEMT-Easy (Promega) and used to generate sense or antisense RNA probes. Sections were deparaffinized with xylene and rehydrated through an ethanol series and PBS. Sections were fixed in 4\% PFA for 15 minutes and then washed with PBS. The sections were treated with $8 \mu \mathrm{g} / \mathrm{ml}$ proteinase $\mathrm{K}$ in $\mathrm{PBS}$ for 30 minutes at $37^{\circ} \mathrm{C}$, washed with $\mathrm{PBS}$, refixed with $4 \% \mathrm{PFA}$, washed again with $\mathrm{PBS}$, and placed in $0.2 \mathrm{~N} \mathrm{HCl}$ for 10 minutes. After washing with PBS, the sections were acetylated by incubation in $0.1 \mathrm{M}$ triethanolamine- $\mathrm{HCl}$ (158917, MilliporeSigma) ( $\mathrm{pH} 8.0$, containing $0.25 \%$ acetic anhydride) for 10 minutes. After washing with PBS, the sections were dehydrated through an ethanol series. Hybridization was performed with probes at concentrations of $300 \mathrm{ng} / \mathrm{ml}$ for 16 hours at $60^{\circ} \mathrm{C}$. After hybridization, sections were washed in $5 \times$ HybriWash (SHW-01, Genostaff, equivalent to $5 \times \mathrm{SSC}$ ) at $60^{\circ} \mathrm{C}$ for 20 minutes, then in $50 \%$ formamide, $2 \times$ HybriWash at $60^{\circ} \mathrm{C}$ for 20 minutes, followed by RNase treatment in $50 \mu \mathrm{g} / \mathrm{ml} \mathrm{RNase}$ A in $10 \mathrm{mM}$ Tris- $\mathrm{HCl}\left(\mathrm{pH} 8.0\right.$, containing $1 \mathrm{M} \mathrm{NaCl}$ and $1 \mathrm{mM}$ EDTA) for 30 minutes at $37^{\circ} \mathrm{C}$. Then, the sections were washed twice with $2 \times$ HybriWash at $60^{\circ} \mathrm{C}$ for 20 minutes, twice with $0.2 \times$ HybriWash at $60^{\circ} \mathrm{C}$ for 20 minutes, and once with TBS/T (0.1\% Tween 20 in TBS). After treatment with G-block (GB-01, Genostaff) for 30 minutes, the sections were incubated with anti-digoxigenin antibody (11093274910, Roche Diagnostics) conjugated with alkaline phosphatase $(1: 1,000)$ for 2 hours at room temperature. The sections were washed twice with TBS/T and then incubated in $100 \mathrm{mM} \mathrm{NaCl}, 50 \mathrm{mM} \mathrm{MgCl}, 0.1 \%$ Tween 20, and $100 \mathrm{mM}$ Tris- $\mathrm{HCl}$ (pH 9.5). Development reactions were performed in NBT/BCIP solution (11681451001, 
Roche Diagnostics) overnight, followed by washing with PBS. The sections were counterstained with Kernechtrot stain solution (N3020, MilliporeSigma), dehydrated, and then mounted with Malinol (20091, Muto Pure Chemicals Co. Ltd.).

Immunofluorescence staining. Samples were blocked with $2 \%$ goat serum in PBS containing $2 \%$ Triton X-100 (PBST) (064K0164, Roche Diagnostics) for 1 hour at room temperature. Then, samples were incubated with primary antibodies for 3 days at $4^{\circ} \mathrm{C}$ with gentle agitation. The sections were washed 3 times with PBST at room temperature for 10 minutes and incubated with secondary antibodies for 1 hour at room temperature. Alexa 488- or Alexa 546-conjugated secondary antibodies (1:1,000, A11034 and A11010, Molecular Probes) were used. Primary and secondary antibodies were diluted in blocking buffer and PBST containing $0.3 \%$ goat serum, respectively. Nuclei were stained with DAPI (100 $\mu \mathrm{g} / \mathrm{ml}$, Dojindo). Fluorescent images were acquired with a FV1200 laser scanning confocal microscope (Olympus) or BV-8000 (Keyence).

mfERG. mfERGs were recorded using a VERIS 6.0 system (Electro-Diagnostic Imaging) as previously reported (90). Mice were anesthetized with a mixture of xylazine $(10 \mathrm{mg} / \mathrm{kg})$ and ketamine $(25 \mathrm{mg} / \mathrm{kg}$; i.p.). Four- or 13-month-old mice were considered young or aged mice, respectively. The pupils were dilated with $0.5 \%$ phenylephrine hydrochloride and $0.5 \%$ tropicamide. The visual stimulus consisted of 7 hexagonal areas scaled with eccentricity. The stimulus array was displayed on a high-resolution black and white monitor driven at a frame rate of $100 \mathrm{~Hz}$. The second-order kernel, impaired in glaucoma patients (91), was analyzed.

SBF-SEM. Enucleated eyes were immersed in 0.1 M PBS containing 4\% PFA (163-25983, Wako) and $0.5 \%$ glutaraldehyde (077-06271, Wako) for 3 hours at room temperature. Then, the hemisphere including the cornea and $\mathrm{CB}$ were dissected and further fixed for 12 hours at $4^{\circ} \mathrm{C}$. Optic nerve sections were cut on a vibratome (Leica), and the specimens were stained with $0.4 \% \mathrm{OsO} 4$, uranyl acetate, and lead aspartate, followed by embedding in Epon resin (Electronic Microscopy Sciences). SBF-SEM images were obtained using a Sigma VP SEM (Carl Zeiss).

Analysis of cornea structures. Enucleated eyes were fixed with 4\% PFA for 1 hour at room temperature, and corneas were dissected. Specimens were stained with DAPI $(10 \mu \mathrm{g} / \mathrm{ml}$ in PBS $)$ for 1 hour at room temperature and mounted on a glass slide. Cell layers were imaged by z-stack imaging using an FV-1200 laser scanning confocal microscope (Olympus).

Primary cultured epithelial cells from the $C B$. Enucleated eyes were immediately immersed in PBS, and the ciliary bodies were isolated. The tissue was then sliced using a McIlwain tissue chopper (Mickle Laboratory Engineering). The slices were attached to a $\mu$-dish (ibidi $\mathrm{GmbH}$ ) and cultured in DMEM (11885-084, Gibco) supplemented with $10 \% \mathrm{FBS}, 100 \mathrm{units} / \mathrm{ml}$ of penicillin, and $100 \mu \mathrm{g} / \mathrm{ml}$ of streptomycin under $10 \%$ $\mathrm{CO}_{2}$ at $37^{\circ} \mathrm{C}$ with medium changes every few days. NPE cells were identified as transparent cells under visible light images. $\mathrm{PE}$ cells contained brown depositions.

$\mathrm{Ca}^{2+}$ imaging. $\mathrm{Ca}^{2+}$ imaging was performed as previously reported with minor modifications $(76,92)$. Briefly, culture medium was replaced with balanced salt solution (BSS) of the following composition (in $\mathrm{mM}$ ): $\mathrm{NaCl} 150, \mathrm{KCl} 5.0, \mathrm{CaCl}_{2} 1.8, \mathrm{MgCl}_{2}$ 1.2, HEPES 25, and D-glucose 10 ( $\mathrm{pH} 7.4$ ). Cells were loaded with fluo-4AM (5 $\mu \mathrm{M})$ (M14206, Thermo Fisher Scientific) for 30 minutes at room temperature. Samples were mounted on a microscope (IX-71, Olympus) equipped with a mercury burner U-RFL-T as a light source in conjunction with a standard fluorescein filter set. Image data were recorded using a CCD camera (ORCA-ER, C4742-95-12ER, Hamamatsu Photonics).

Statistics. Data are expressed as means \pm SEM. Two-tailed unpaired $t$ tests or Mann-Whitney $U$ tests were used for the comparison of 2 groups. One-way ANOVA, followed by Fisher's LSD test, was applied for multiple comparisons. The differences were considered to be significant when the $P$ value was less than 0.05 .

Study approval. All animals used in this study were obtained, housed, cared for and used in accordance with the Association for Research in Vision and Ophthalmology statement on the use of animals in ophthalmic research and the "Guiding Principles in the Care and Use of Animals in the Field of Physiological Sciences" published by the Physiological Society of Japan and with previous approval of the Animal Care Committee of Yamanashi University (Chuo, Yamanashi, Japan).

\section{Author contributions}

YS designed, performed, and analyzed experiments described in each figure and wrote the manuscript. KN and TH performed mfERG and analyzed the data. AT performed experiments described in some figures. NO performed SBF-SEM and analyzed the data. BR and TI provided technical assistance and analyzed data. KK and SK coordinated the project, analyzed the data, and wrote the manuscript. 


\section{Acknowledgments}

We thank R. Kuwahara, I. Saito, Y. Watanabe, Y. Fukasawa, and M. Tachibana from the Department of Ophthalmology and Neuropharmacology, Interdisciplinary Graduate School of Medicine, University of Yamnashi, and we thank T. Noro of the Tokyo Metropolitan Institute of Medical Science for technical assistance. We also thank E. Shigetomi, K. Shibata, Y. Hirayama, B. Parajuli, F. Sano, M. Tanaka, L.P.N. Ha, Y. Hirayama, K. Kubota, H. Tsuzukiyama, Y. Danjo, T. Okuda, S. Takeda, and M. Yabusaki from the Department of Neuropharmacology, Interdisciplinary Graduate School of Medicine, University of Yamnashi, for their fruitful discussions. This study was supported by the Takeda Science Foundation (to YS and TH), the Ichiro Kanehara Foundation for the Promotion of Medical Sciences and Medical Care (to YS), the Japan Agency for Medical Research and Development (grant 16ek0109072h0003, to TI), JSPS KAKENHI grants (JP16K18390 to YS, JP16K08635 to KN, JP16H06280 to NO, JP15H04999 to TH, JP16H04669 to SK, and JP25117003 to SK), the Cooperative Research Program of Network Joint Research Center for Materials and Devices (to NO), and a Grant-in-Aid for Scientific Research on Innovative Areas-Resource and technical support platforms for promoting research of Advanced Bioimaging Support (JP16H06280) (to YS and NO). This study is also partially supported by JST grant CREST number JPMJCR14G2 (to SK) and AMED-CREST (to SK). We thank J. Ludovic Croxford, from Edanz Group (www.edanzediting.com/ac) for editing a draft of this manuscript.

Address correspondence to: Schuichi Koizumi, Department of Neuropharmacology, Interdisciplinary Graduate School of Medicine, University of Yamanashi, 1110 Shimokato, Chuo, Yamanashi 409-3898, Japan. Phone: 81.55.273.9503; Email: skoizumi@yamanashi.ac.jp.

1. Quigley HA. Number of people with glaucoma worldwide. Br J Ophthalmol. 1996;80(5):389-393.

2. Weinreb RN, Aung T, Medeiros FA. The pathophysiology and treatment of glaucoma: a review. JAMA. 2014;311(18):1901-1911.

3. Heijl A, et al. Reduction of intraocular pressure and glaucoma progression: results from the Early Manifest Glaucoma Trial. Arch Ophthalmol. 2002;120(10):1268-1279.

4. Kass MA, et al. The Ocular Hypertension Treatment Study: a randomized trial determines that topical ocular hypotensive medication delays or prevents the onset of primary open-angle glaucoma. Arch Ophthalmol. 2002;120(6):701-713.

5. Pintor J, Peláez T, Peral A. Adenosine tetraphosphate, Ap4, a physiological regulator of intraocular pressure in normotensive rabbit eyes. J Pharmacol Exp Ther. 2004;308(2):468-473.

6. Shahidullah M, Mandal A, Beimgraben C, Delamere NA. Hyposmotic stress causes ATP release and stimulates Na,K-ATPase activity in porcine lens. J Cell Physiol. 2012;227(4):1428-1437.

7. Luna C, Li G, Qiu J, Challa P, Epstein DL, Gonzalez P. Extracellular release of ATP mediated by cyclic mechanical stress leads to mobilization of AA in trabecular meshwork cells. Invest Ophthalmol Vis Sci. 2009;50(12):5805-5810.

8. Reigada D, Lu W, Zhang M, Mitchell CH. Elevated pressure triggers a physiological release of ATP from the retina: possible role for pannexin hemichannels. Neuroscience. 2008;157(2):396-404.

9. Gomes P, Srinivas SP, Van Driessche W, Vereecke J, Himpens B. ATP release through connexin hemichannels in corneal endothelial cells. Invest Ophthalmol Vis Sci. 2005;46(4):1208-1218.

10. Xia J, et al. Neurons respond directly to mechanical deformation with pannexin-mediated ATP release and autostimulation of P2X7 receptors. J Physiol (Lond). 2012;590(10):2285-2304

11. Beckel JM, et al. Mechanosensitive release of adenosine 5'-triphosphate through pannexin channels and mechanosensitive upregulation of pannexin channels in optic nerve head astrocytes: a mechanism for purinergic involvement in chronic strain. Glia. 2014;62(9):1486-1501.

12. Mitchell CH, Carré DA, McGlinn AM, Stone RA, Civan MM. A release mechanism for stored ATP in ocular ciliary epithelial cells. Proc Natl Acad Sci U S A. 1998;95(12):7174-7178.

13. Li A, Zhang X, Zheng D, Ge J, Laties AM, Mitchell CH. Sustained elevation of extracellular ATP in aqueous humor from humans with primary chronic angle-closure glaucoma. Exp Eye Res. 2011;93(4):528-533.

14. Zhang X, Li A, Ge J, Reigada D, Laties AM, Mitchell CH. Acute increase of intraocular pressure releases ATP into the anterior chamber. Exp Eye Res. 2007;85(5):637-643.

15. Khakh BS, Burnstock G. The double life of ATP. Sci Am. 2009;301(6):84-90.

16. Pintor J, Sánchez-Nogueiro J, Irazu M, Mediero A, Peláez T, Peral A. Immunolocalisation of P2Y receptors in the rat eye. Purinergic Signal. 2004;1(1):83-90.

17. Eliahu S, et al. 2-MeS-beta,gamma-CCl2-ATP is a potent agent for reducing intraocular pressure. JMed Chem. 2010;53(8):3305-3319.

18. Soto D, Pintor J, Peral A, Gual A, Gasull X. Effects of dinucleoside polyphosphates on trabecular meshwork cells and aqueous humor outflow facility. J Pharmacol Exp Ther. 2005;314(3):1042-1051.

19. Martin-Gil A, de Lara MJ, Crooke A, Santano C, Peral A, Pintor J. Silencing of P2Y(2) receptors reduces intraocular pressure in New Zealand rabbits. Br J Pharmacol. 2012;165(4b):1163-1172.

20. Markovskaya A, Crooke A, Guzmán-Aranguez AI, Peral A, Ziganshin AU, Pintor J. Hypotensive effect of UDP on intraocular pressure in rabbits. Eur J Pharmacol. 2008;579(1-3):93-97.

21. Civan MM, Macknight AD. The ins and outs of aqueous humour secretion. Exp Eye Res. 2004;78(3):625-631.

22. Johnson M, McLaren JW, Overby DR. Unconventional aqueous humor outflow: a review. Exp Eye Res. 2017;158:94-111.

23. Moura AL, Raza AS, Lazow MA, De Moraes CG, Hood DC. Retinal ganglion cell and inner plexiform layer thickness mea- 
surements in regions of severe visual field sensitivity loss in patients with glaucoma. Eye (Lond). 2012;26(9):1188-1193.

24. Raza AS, et al. Retinal ganglion cell layer thickness and local visual field sensitivity in glaucoma. Arch Ophthalmol. 2011;129(12):1529-1536.

25. Wang $M$, et al. Measurement of local retinal ganglion cell layer thickness in patients with glaucoma using frequency-domain optical coherence tomography. Arch Ophthalmol. 2009;127(7):875-881.

26. Fortune B, Cull G, Reynaud J, Wang L, Burgoyne CF. Relating retinal ganglion cell function and retinal nerve fiber layer (RNFL) retardance to progressive loss of RNFL thickness and optic nerve axons in experimental glaucoma. Invest Ophthalmol Vis Sci. 2015;56(6):3936-3944.

27. Luo X, Patel NB, Rajagopalan LP, Harwerth RS, Frishman LJ. Relation between macular retinal ganglion cell/inner plexiform layer thickness and multifocal electroretinogram measures in experimental glaucoma. Invest Ophthalmol Vis Sci. 2014;55(7):4512-4524.

28. Dielemans I, Vingerling JR, Wolfs RC, Hofman A, Grobbee DE, de Jong PT. The prevalence of primary open-angle glaucoma in a population-based study in The Netherlands. The Rotterdam Study. Ophthalmology. 1994;101(11):1851-1855.

29. Leske MC, Connell AM, Wu SY, Hyman LG, Schachat AP. Risk factors for open-angle glaucoma. The Barbados Eye Study. Arch Ophthalmol. 1995;113(7):918-924.

30. Suzuki Y, et al. Risk factors for open-angle glaucoma in a Japanese population: the Tajimi Study. Ophthalmology. 2006;113(9):1613-1617.

31. Wensor MD, McCarty CA, Stanislavsky YL, Livingston PM, Taylor HR. The prevalence of glaucoma in the Melbourne Visual Impairment Project. Ophthalmology. 1998;105(4):733-739.

32. Kohno H, et al. Photoreceptor proteins initiate microglial activation via Toll-like receptor 4 in retinal degeneration mediated by all-trans-retinal. J Biol Chem. 2013;288(21):15326-15341.

33. Pintor J, Peral A, Peláez T, Martín S, Hoyle CH. Presence of diadenosine polyphosphates in the aqueous humor: their effect on intraocular pressure. J Pharmacol Exp Ther. 2003;304(1):342-348.

34. Eldred JA, Sanderson J, Wormstone M, Reddan JR, Duncan G. Stress-induced ATP release from and growth modulation of human lens and retinal pigment epithelial cells. Biochem Soc Trans. 2003;31(pt 6):1213-1215.

35. Fleischhauer JC, Mitchell CH, Stamer WD, Karl MO, Peterson-Yantorno K, Civan MM. Common actions of adenosine receptor agonists in modulating human trabecular meshwork cell transport. J Membr Biol. 2003;193(2):121-136.

36. Newman EA. Propagation of intercellular calcium waves in retinal astrocytes and Müller cells. J Neurosci. 2001;21(7):2215-2223.

37. Newman EA. Glial cell inhibition of neurons by release of ATP. J Neurosci. 2003;23(5):1659-1666.

38. Li A, Leung CT, Peterson-Yantorno K, Mitchell CH, Civan MM. Pathways for ATP release by bovine ciliary epithelial cells, the initial step in purinergic regulation of aqueous humor inflow. Am J Physiol Cell Physiol. 2010;299(6):C1308-C1317.

39. Fonseca B, Martínez-Águila A, de Lara MJP, Pintor J. Diadenosine tetraphosphate as a potential therapeutic nucleotide to treat glaucoma. Purinergic Signal. 2017;13(2):171-177.

40. Castany M, et al. Glaucoma patients present increased levels of diadenosine tetraphosphate, Ap(4)A, in the aqueous humour. Exp Eye Res. 2011;92(3):221-226.

41. Helal J, Macri FJ, Cevario SJ. Timolol inhibition of aqueous humor production in the cat. Gen Pharmacol. 1979;10(5):377-380

42. McLaughlin CW, et al. Timolol may inhibit aqueous humor secretion by cAMP-independent action on ciliary epithelial cells. Am J Physiol Cell Physiol. 2001;281(3):C865-C875.

43. Schenker HI, Yablonski ME, Podos SM, Linder L. Fluorophotometric study of epinephrine and timolol in human subjects. Arch Ophthalmol. 1981;99(7):1212-1216.

44. Watanabe K, Chiou GC. Action mechanism of timolol to lower the intraocular pressure in rabbits. Ophthalmic Res. 1983;15(3):160-167.

45. Crook RB, Takahashi K, Mead A, Dunn JJ, Sears ML. The role of NaKCl cotransport in blood-to-aqueous chloride fluxes across rabbit ciliary epithelium. Invest Ophthalmol Vis Sci. 2000;41(9):2574-2583.

46. Do CW, Civan MM. Basis of chloride transport in ciliary epithelium. J Membr Biol. 2004;200(1):1-13.

47. Do CW, To CH. Chloride secretion by bovine ciliary epithelium: a model of aqueous humor formation. Invest Ophthalmol Vis Sci. 2000;41(7):1853-1860.

48. Kishida K, Sasabe T, Iizuka S, Manabe R, Otori T. Sodium and chloride transport across the isolated rabbit ciliary body. Curr Eye Res. 1982;2(3):149-152.

49. To CH, Do CW, Zamudio AC, Candia OA. Model of ionic transport for bovine ciliary epithelium: effects of acetazolamide and HCO. Am J Physiol Cell Physiol. 2001;280(6):C1521-C1530.

50. To CH, Mok KH, Do CW, Lee KL, Millodot M. Chloride and sodium transport across bovine ciliary body/epithelium (CBE) Curr Eye Res. 1998;17(9):896-902.

51. Clouet S, et al. Loss of mouse P2Y6 nucleotide receptor is associated with physiological macrocardia and amplified pathological cardiac hypertrophy. J Biol Chem. 2016;291(30):15841-15852.

52. Köttgen $\mathrm{M}$, et al. P2Y6 receptor mediates colonic $\mathrm{NaCl}$ secretion via differential activation of cAMP-mediated transport. J Clin Invest. 2003;111(3):371-379.

53. Chen S, Inoue R, Inomata H, Ito Y. Role of cyclic AMP-induced Cl conductance in aqueous humour formation by the dog ciliary epithelium. Br J Pharmacol. 1994;112(4):1137-1145.

54. Civan MM, Coca-Prados M, Peterson-Yantorno K. Pathways signaling the regulatory volume decrease of cultured nonpigmented ciliary epithelial cells. Invest Ophthalmol Vis Sci. 1994;35(6):2876-2886.

55. Caprioli J, Sears M. Forskolin lowers intraocular pressure in rabbits, monkeys, and man. Lancet. 1983;1(8331):958-960.

56. Do CW, Kong CW, To CH. cAMP inhibits transepithelial chloride secretion across bovine ciliary body/epithelium. Invest Ophthalmol Vis Sci. 2004;45(10):3638-3643.

57. Lee PY, Podos SM, Mittag T, Severin C. Effect of topically applied forskolin on aqueous humor dynamics in cynomolgus monkey. Invest Ophthalmol Vis Sci. 1984;25(10):1206-1209.

58. Howe K, Gauldie J, McKay DM. TGF- $\beta$ effects on epithelial ion transport and barrier: reduced $\mathrm{Cl}^{-}$secretion blocked by a p38 MAPK inhibitor. Am J Physiol Cell Physiol. 2002;283(6):C1667-C1674. 
59. Nakamura T, Murata T, Hori M, Ozaki H. UDP induces intestinal epithelial migration via the P2Y6 receptor. Br J Pharmacol. 2013;170(4):883-892.

60. Nishida M, et al. P2Y6 receptor-Galpha12/13 signalling in cardiomyocytes triggers pressure overload-induced cardiac fibrosis EMBO J. 2008;27(23):3104-3115.

61. Law CS, Candia OA, To CH. Inhibitions of chloride transport and gap junction reduce fluid flow across the whole porcine ciliary epithelium. Invest Ophthalmol Vis Sci. 2009;50(3):1299-1306.

62. Kléber $\mathrm{G}$. The potential role of $\mathrm{Ca}^{2+}$ for electrical cell-to-cell uncoupling and conduction block in myocardial tissue. Basic Res Cardiol. 1992;87 Suppl 2:131-143.

63. Oliveira-Castro GM, Loewenstein WR. Junctional membrane permeability: effects of divalent cations. J Membr Biol. 1971;5(1):51-77.

64. Rose B, Loewenstein WR. Permeability of cell junction depends on local cytoplasmic calcium activity. Nature 1975;254(5497):250-252.

65. Erlinge D. Extracellular ATP: a growth factor for vascular smooth muscle cells. Gen Pharmacol. 1998;31(1):1-8.

66. Nicholas RA, Lazarowski ER, Watt WC, Li Q, Boyer J, Harden TK. Pharmacological and second messenger signalling selectivities of cloned P2Y receptors. J Auton Pharmacol. 1996;16(6):319-323.

67. Babalola OE, Kehinde AV, Iloegbunam AC, Akinbinu T, Moghalu C, Onuoha I. A comparison of the Goldmann applanation and non-contact (Keeler Pulsair EasyEye) tonometers and the effect of central corneal thickness in indigenous African eyes. Ophthalmic Physiol Opt. 2009;29(2):182-188.

68. Bhan A, Browning AC, Shah S, Hamilton R, Dave D, Dua HS. Effect of corneal thickness on intraocular pressure measurements with the pneumotonometer, Goldmann applanation tonometer, and Tono-Pen. Invest Ophthalmol Vis Sci. 2002;43(5):1389-1392.

69. Browning AC, Bhan A, Rotchford AP, Shah S, Dua HS. The effect of corneal thickness on intraocular pressure measurement in patients with corneal pathology. Br J Ophthalmol. 2004;88(11):1395-1399.

70. Harada Y, Hirose N, Kubota T, Tawara A. The influence of central corneal thickness and corneal curvature radius on the intraocular pressure as measured by different tonometers: noncontact and goldmann applanation tonometers. J Glaucoma. 2008;17(8):619-625.

71. Ko YC, Liu CJ, Hsu WM. Varying effects of corneal thickness on intraocular pressure measurements with different tonometers. Eye (Lond). 2005;19(3):327-332.

72. Murase H, Sawada A, Mochizuki K, Yamamoto T. Effects of corneal thickness on intraocular pressure measured with three different tonometers. Jpn J Ophthalmol. 2009;53(1):1-6.

73. Rao A, Kumar M, Prakash B, Varshney G. Relationship of central corneal thickness and intraocular pressure by iCare rebound tonometer. J Glaucoma. 2014;23(6):380-384.

74. Saleh TA, Adams M, McDermott B, Claridge KG, Ewings P. Effects of central corneal thickness and corneal curvature on the intraocular pressure measurement by Goldmann applanation tonometer and ocular blood flow pneumatonometer. Clin Experiment Ophthalmol. 2006;34(6):516-520.

75. Tonnu PA, et al. The influence of central corneal thickness and age on intraocular pressure measured by pneumotonometry, non-contact tonometry, the Tono-Pen XL, and Goldmann applanation tonometry. Br J Ophthalmol. 2005;89(7):851-854.

76. Taguchi M, Shinozaki Y, Kashiwagi K, Shigetomi E, Robaye B, Koizumi S. Müller cell-mediated neurite outgrowth of the retinal ganglion cells via P2Y6 receptor signals. J Neurochem. 2016;136(4):741-751.

77. Koizumi S, et al. UDP acting at P2Y6 receptors is a mediator of microglial phagocytosis. Nature. 2007;446(7139):1091-1095.

78. Crish SD, Sappington RM, Inman DM, Horner PJ, Calkins DJ. Distal axonopathy with structural persistence in glaucomatous neurodegeneration. Proc Natl Acad Sci U S A. 2010;107(11):5196-5201.

79. Bosco A, Steele MR, Vetter ML. Early microglia activation in a mouse model of chronic glaucoma. J Comp Neurol. 2011;519(4):599-620.

80. Yuan L, Neufeld AH. Activated microglia in the human glaucomatous optic nerve head. J Neurosci Res. 2001;64(5):523-532.

81. Bosco A, et al. Reduced retina microglial activation and improved optic nerve integrity with minocycline treatment in the DBA/2J mouse model of glaucoma. Invest Ophthalmol Vis Sci. 2008;49(4):1437-1446.

82. Lee H, Choi BH, Suh BC, Lee SK, Kim KT. Attenuation of signal flow from P2Y6 receptor by protein kinase C-alpha in SK-N-BE(2) C human neuroblastoma cells. J Neurochem. 2003;85(4):1043-1053.

83. Ito M, Matsuoka I. Inhibition of P2Y6 receptor-mediated phospholipase $\mathrm{C}$ activation and $\mathrm{Ca}(2+)$ signalling by prostaglandin E2 in J774 murine macrophages. Eur J Pharmacol. 2015;749:124-132.

84. Busquets X, Ventayol P, Sastre M, García-Sevilla JA. Age-dependent increases in protein kinase C-alpha beta immunoreactivity and activity in the human brain: possible in vivo modulatory effects on guanine nucleotide regulatory G(i) proteins. Brain Res. 1996;710(1-2):28-34.

85. Wu D, et al. Age-associated increase in PGE2 synthesis and COX activity in murine macrophages is reversed by vitamin E. Am J Physiol. 1998;275(3 pt 1):C661-C668.

86. Bar I, et al. Knockout mice reveal a role for P2Y6 receptor in macrophages, endothelial cells, and vascular smooth muscle cells. Mol Pharmacol. 2008;74(3):777-784.

87. Yamada T, et al. A progressive scan CCD image sensor for DSC applications. IEEE J. Solid-State Circuits . 2000;35(12):2044-2054

88. Kaneko Y, et al. Effects of K-115 (Ripasudil), a novel ROCK inhibitor, on trabecular meshwork and Schlemm's canal endothelial cells. Sci Rep. 2016;6:19640.

89. Avila MY, Mitchell CH, Stone RA, Civan MM. Noninvasive assessment of aqueous humor turnover in the mouse eye. Invest Ophthalmol Vis Sci. 2003;44(2):722-727.

90. Harada T, et al. The potential role of glutamate transporters in the pathogenesis of normal tension glaucoma. J Clin Invest. 2007;117(7):1763-1770

91. Sutter EE, Bearse MA. The optic nerve head component of the human ERG. Vision Res. 1999;39(3):419-436.

92. Shinozaki Y, Nomura M, Iwatsuki K, Moriyama Y, Gachet C, Koizumi S. Microglia trigger astrocyte-mediated neuroprotection via purinergic gliotransmission. Sci Rep. 2014;4:4329. 